\title{
CHECKLIST OF MURIDS (MAMMALIA: RODENTIA: MURIDAE) OF SOUTH ASIA
}

\author{
C. Srinivasulu ${ }^{1}$ and M.S. Pradhan ${ }^{2}$ \\ ${ }^{1}$ Research Associate (Wildlife), Wildlife Biology Section, Department of Zoology, University College of Science (A), Osmania University, \\ Hyderabad, Andhra Pradesh 500007, India. \\ ${ }^{2}$ Western Regional Station, Zoological Survey of India, Vidyanagar, Sector 29, Rawet Road, PCNTDA Post, Pune, \\ Maharashtra 411044, India. \\ Email: ${ }^{1}$ masawa@hd2.dot.net.in; ${ }^{2} z$ sipune@mah.nic.in
}

\begin{abstract}
A checklist of 91 species of murids (Mammalia: Rodentia: Muridae) belonging to 33 genera in seven subfamilies known to occur in South Asia is provided.
\end{abstract}

\section{Keywords}

Checklist, Muridae, Rodentia, South Asia

\section{Introduction}

To date the most comprehensive taxonomic work on murids of India including its immediate neighbouring countries and Afghanistan is that of Ellerman (1961). The Rodentia volume of the Fauna of India (Ellerman, 1961) and the key for identification of Indian rodents (Ellerman, 1947a, b) remain an important source of information on rodents of the region of South Asia including Bangladesh, Bhutan, India, Nepal, Pakistan and Sri Lanka. Ellerman (1961) gave descriptive account of 260 subspecies of rodents under 128 species belonging to 46 genera from the Indian subcontinent.

Before Ellerman's monumental work, accounts of rodents of the region were available through the works of Blyth (1863), Jerdon (1874), Sterndale (1884) and Blanford (1888, 1891). In fact, Blanford $(1888,1891)$ provided the first comprehensive work on the rodents of the region including accounts of 93 species and 43 varieties. During the Mammal Survey of India, Burma (Myanmar) and Ceylon (Sri Lanka) by the Bombay Natural History Society between 1919 and 1928, the knowledge about rodents of the region increased manifold, and also resulted in addition of a numerous new species and subspecies from the region.

During recent times, the classification of this order has been subjected to numerous changes (Ellerman \& Morrison-Scott,
1951; Ellerman, 1961; Marshall, 1977a; Carleton \& Musser, 1984; Corbet \& Hill, 1980, 1986, 1991, 1992; Musser \& Carleton, 1993; Agrawal, 2000) due to an increased level of application of taxonomic parameters, awareness regarding taxonomic studies of diversified rodent species, and their intra- and interrelationships throughout the world.

Although, Agrawal (2000) has provided a detailed account on the murids (along with hystricids) of India, the need of a comprehensive list of the murids belonging to South Asia is lacking and its need is inevitable at present. Through this review, an attempt has been made to put together one such list of murid species including information on their synonyms and subspecies.

\section{Methods}

Present work on the rodents of South Asia region is primarily based on Corbet and Hill (1992), Musser and Carleton (1993), Agrawal (2000) and a list prepared by Mike Jordan from United Kingdom. We reviewed major references like Ellerman (1947a, b; 1961), Ellerman and Morrison-Scott (1951, 1953), Roberts (1997), Phillips (1980), Corbet and Hill (1991, 1992), Musser and Carleton (1993), and Agrawal (2000) to compile this checklist. Besides these, we also referred to numerous other sources for information: Fry (1931), Roonwal (1948, 1949, 1950), Biswas and Tiwari (1969), Agrawal (1967a, b, 1970, 1973), Agrawal and Chakraborty $(1971,1976,1981,1982)$, Chakraborty $(1975,1983)$, Saha (1980), Biswas and Khajuria (1955, 1957), Pradhan (1979), Pradhan and Mithel (1981), Pradhan et al. (1989, 1993), and Pradhan et al. (communicated). Deriving information from various sources listed above, we have listed the species of murids known to occur in South Asia including India, Pakistan, Nepal, Bhutan, Bangladesh and Sri Lanka. For all practical purposes we consider the disputed land of Pakistan-occupiedKashmir as a part of India, and species endemic to the disputed

Received 21 January 2003; $\quad$ Revised received 20 April 2003; $\quad$ Finally accepted 28 September 2003 
area have been included in this review as 'Endemic to the region known from disputed land of Pakistan-occupied-Kashmir'. For species with wider distribution in India and Pakistan we do not mention so presuming it to be understood, but 'Pakistanoccupied-Kashmir' is included for species that are restricted in distribution to either Pakistan or other parts of northern India, and the disputed land. For species restricted or distributed in other than the disputed land in India we mention 'Jammu \& Kashmir in India'. As we are not aware of rodents of Maldive Islands, we are not taking that country into account under the

Table 1. Species diversity of Family Muridae in South Asia

\begin{tabular}{|c|c|c|c|}
\hline Subfamily & Genus & $\begin{array}{l}\text { No. of } \\
\text { species }\end{array}$ & Remarks \\
\hline \multirow[t]{5}{*}{ Arvicolinae } & Alticola & 7 & $\begin{array}{l}2 \text { regional, } 2 \text { Indian } \\
\text { endemics }\end{array}$ \\
\hline & Ellobius & 1 & \\
\hline & Eothenomys & 1 & \\
\hline & Hyperacrius & 2 & 2 regional endemics \\
\hline & Microtus & 3 & including Pitymys \\
\hline Calomyscinae & Calomyscus & 2 & 1 Pakistan endemic \\
\hline Cricetinae & Cricetulus & 2 & \\
\hline \multirow[t]{4}{*}{ Gerbillinae } & Gerbillus & 4 & 1 regional endemic \\
\hline & Meriones & 4 & \\
\hline & Rhombomys & 1 & \\
\hline & Tatera & 1 & \\
\hline \multirow[t]{19}{*}{ Murinae } & Acomys & 1 & \\
\hline & Apodemus & 5 & 1 Nepal endemic \\
\hline & Bandicota & 3 & \\
\hline & Berylmys & 3 & \\
\hline & Chiropodomys & 1 & \\
\hline & Cremnomys & 3 & $\begin{array}{l}1 \text { regional, } 2 \text { Indian } \\
\text { endemics }\end{array}$ \\
\hline & Dacnomys & 1 & Monotypic \\
\hline & Diomys & 1 & $\begin{array}{l}\text { Monotypic; regional } \\
\text { endemic }\end{array}$ \\
\hline & Golunda & 1 & \\
\hline & Hadromys & 1 & Monotypic \\
\hline & Leopoldamys & 2 & \\
\hline & Micromys & 1 & Monotypic \\
\hline & Millardia & 3 & $\begin{array}{l}2 \text { regional, } 1 \text { Indian } \\
\text { endemic }\end{array}$ \\
\hline & Mus & 11 & $\begin{array}{l}2 \text { regional, } 2 \text { Indian, } \\
2 \text { Sri Lankan endemics }\end{array}$ \\
\hline & Nesokia & 1 & \\
\hline & Niviventer & 6 & 1 regional endemic \\
\hline & Rattus & 13 & $\begin{array}{l}1 \text { regional, } 4 \text { Indian, } \\
1 \text { Sri Lankan endemic }\end{array}$ \\
\hline & Srilankamys & 1 & Sri Lankan endemic \\
\hline & Vandeleuria & 2 & 1 Sri Lankan endemic \\
\hline Platacanthomyinae & Platacanthomys & 1 & $\begin{array}{l}\text { Monotypic; Indian } \\
\text { endemic }\end{array}$ \\
\hline \multirow[t]{2}{*}{ Rhizomyinae } & Cannomys & 1 & Monotypic \\
\hline & Rhizomys & 1 & \\
\hline
\end{tabular}

Table 2. Insular endemic species belonging to Family Muridae in South Asia

\begin{tabular}{|c|c|c|}
\hline Scientific name & Distribution & Remarks \\
\hline \multicolumn{3}{|l|}{ Murinae } \\
\hline Mus fernandoni & Sri Lanka & \\
\hline Mus mayori & Sri Lanka & \\
\hline Rattus burrus & Andaman \& Nicobar Is. & only from Nicobar Isles \\
\hline Rattus montanus & Sri Lanka & \\
\hline Rattus palmarum & Andaman \& Nicobar Is. & only from Nicobar Isles \\
\hline Rattus stoicus & Andaman \& Nicobar Is. & only from Andaman Isles \\
\hline Srilankamys ohiensis & Sri Lanka & \\
\hline Vandeleuria nolthenii & Sri Lanka & \\
\hline
\end{tabular}

present review. This list is based on the best of the present knowledge, on murid diversity of the region to date.

\section{Results}

A total of 91 species of murids belonging to 33 genera and seven subfamilies are recorded from South Asia. Fourteen species belong to subfamily Arvicolinae, two species to Calomyscinae, two species to Cricetinae, 10 species to Gerbillinae, 60 species to Murinae, one species to Platacanthomyinae, and two species to Rhizomyinae (Table 1).

Of this diversity, 32 species ( 35 percent) are endemic to South Asia of which only 13 species are found in more than one country, while the rest are restricted in distribution to one country. India has 12, Sri Lanka has five, while Nepal and Pakistan have one endemic species each (Table 1). Further, it could be concluded that the following genera, namely, Hyperacrius Miller, 1896, Cremnomys Wroughton, 1912, Diomys Thomas, 1917, Millardia Thomas, 1911, Srilankamys Musser, 1981 and Platacanthomys Blyth, 1859 are endemic to the region. Among the endemics, eight species are insular in nature (Table 2 ) with five species from Sri Lanka and the rest from Andaman $\&$ Nicobar Islands.

The present known murid diversity on record from South Asia is listed below. The synonyms provided are those applicable for the South Asian region only. We have not listed extralimital synonyms that may be valid for some taxon elsewhere. 


\section{Family: Muridae Subfamily: Arvicolinae \\ Genus Alticola Blanford, 1881 Mountain Voles}

This genus belongs to the subfamily Arvicolinae and is represented by seven species in the region. Two species each are endemic to the region and India. Ellerman (1961) has listed two species from the region. Corbet and Hill (1992) has made a brief reference about the species belonging to this genus.

\section{Alticola albicauda (True, 1894)}

1894. Arvicola albicauda True, Proc. U. S. nation. Mus., 17: 12. Name: White-tailed Mountain Vole

Type locality: Braldu Valley, Baltistan, Jammu \& Kashmir, India Synonyms: Arvicola albicauda True, 1894

Alticola roylei albicauda (True, 1894)

Alticola acmaeus Schwarz, 1939

Alticola roylei acmaeus Schwarz, 1939

Subspecies: None

Distribution: Endemic to the region known from disputed land of Pakistan-occupied-Kashmir.

Comments: Ellerman (1961) opined that the skins that were accorded to Alticola roylei albicauda (True, 1894) by Hinton (1926) are closer to Alticola roylei glacialis (Miller, 1913) and goes on to remark that there exist only one specimen of Alticola albicauda (True, 1894). Musser and Carleton (1993) treat it as distinct species and synonymized the name Alticola roylei acmaeus Schwarz, 1939 with it. Agrawal (2000) has not offered any comment on this species.

\section{Alticola argentatus (Severtzov, 1879)}

1879. Arvicola argentata Severtzov, Izv. Soc. Nat. Anthrop. Etnogr., 8,2: 82.

Name: Silver Mountain Vole

Type locality: Mashat, Karatau Mtns., Chimkentskaia Obl., Kazakhstan

Synonyms: Arvicola argentata Severtzov, 1879 Alticola roylei argentata (Severtzov, 1879)

Subspecies: None

Distribution: Jammu \& Kashmir in India, Pakistan-occupiedKashmir and Pakistan.

Comments: Ellerman (1961) and Agrawal (2000) do not comment any thing significant about this species. Ellerman and MorrisonScott (1951) included it under Alticola roylei (Gray, 1842). Musser and Carleton (1993) treat it as a distinct species.

\section{Alticola blanfordi (Scully, 1880)}

1880. Arvicola blanfordi Scully, Ann. Mag. nat. Hist. (5)6: 399.

Name: Scully's Vole

Type locality: Gilgit, Jammu \& Kashmir, India

Synonyms: Arvicola blanfordi Scully, 1880

Alticola roylei blanfordi (Scully, 1880)

Alticola blanfordi lahulius Hinton, 1926

Subspecies: Alticola blanfordi blanfordi (Scully, 1880)

Distribution: Endemic to India. Pakistan-occupied-Kashmir and
Himachal Pradesh in India.

Comments: Ellerman (1961) treated it as subspecies of Alticola roylei (Gray, 1842). Following Ellerman (1961), Agrawal (2000) synonymized Alticola blanfordi lahulius Hinton, 1926 with the nominate subspecies Alticola blanfordi blanfordi (Scully, 1880). Musser and Carleton (1993) treated Alticola blanfordi (Scully, 1880) as a subspecies of Alticola argentatus (Severtzov, 1879), while Agrawal (2000) retained it as a distinct species following Hinton (1926).

\section{Alticola montosa (True, 1894)}

1894. Arvicola montosa True, Proc. U. S. nation. Mus., 17: 11.

Name: True's Vole

Type locality: Central Jammu \& Kashmir, India

Synonyms: Arvicola montosa True, 1894

Microtus imitator Bonhote, 1905

Subspecies: None

Distribution: Endemic to the region. Pakistan-occupied-Kashmir and Pakistan (Agrawal, 2000).

Comments: Ellerman (1961) treated it as a subspecies of Alticola roylei (Gray, 1842). Musser and Carleton (1993) treated it as a distinct species.

\section{Alticola roylei (Gray, 1842)}

1842. Arvicola roylei Gray, Ann. Mag. nat. Hist., (1)10: 265.

Name: Royle's Vole

Type locality: Kumaon, Uttaranchal, India

Synonyms: Arvicola roylei Gray, 1842

Alticola roylei cautus Hinton, 1926

Subspecies: Alticola roylei roylei (Gray, 1842)

Distribution: Himachal Pradesh and Uttaranchal in India. Agrawal (2000) opines that in the present form it is endemic to India.

Comments: Ellerman (1961) treated it as the one of the two Alticola species occurring in the region and listed five subspecies, namely Alticola roylei roylei (Gray, 1842), Alticola roylei cautus Hinton, 1926 - presently synonymized with the nominate subspecies of Alticola roylei (Gray, 1842), Alticola roylei blanfordi (Scully, 1880) - presently Alticola blanfordi (Scully, 1880), Alticola roylei montosa (True, 1894) - presently Alticola montosa (True, 1894), and Alticola roylei glacialis (Miller, 1913). Alticola roylei albicauda (True, 1894) was treated as a form of Alticola roylei glacialis (Miller, 1913) by Ellerman (1961) [See comments under Alticola albicauda (True, 1894)]. Agrawal (2000) could not remark on two subspecies of the Alticola roylei (Gray, 1842), namely Alticola roylei albicauda (True, 1894) and Alticola roylei glacialis (Miller, 1913) due to lack of specimens. Corbet (1978) treated Alticola roylei argentatus as occuring in Pakistan (Roberts, 1997), but this subspecies is now treated as a distinct species by Musser \& Carlton (1993).

\section{Alticola stoliczkanus (Blanford, 1875)}

1875. Arvicola stoliczkanus Blanford, J. Asiatic Soc. Beng., 44(2): 107. 
Name: Stoliczka's Vole

Type locality: Keunlun Mountains, North Ladhak, Jammu \& Kashmir, India

Synonyms: Arvicola stoliczkanus Blanford, 1875

Microtus acrophilus Miller, 1899

Alticola stoliczkanus acrophilus (Miller, 1899)

Subspecies: None

Distribution: Jammu \& Kashmir and Sikkim in India, Nepal and probably Bhutan.

Comments: Ellerman (1961) listed two subspecies, namely Alticola stoliczkanus stoliczkanus (Blanford, 1875) and Alticola stoliczkanus stracheyi (Thomas, 1880). The latter subspecies has been raised to species level, and Agrawal (2000) considers them both as separate species.

\section{Alticola stracheyi (Thomas, 1880)}

1880. Arvicola stracheyi Thomas, Ann. Mag. nat. Hist., (5)6: 332.

Name: Thomas' Short-tailed Vole

Type locality: Ladhak, Jammu \& Kashmir, India

Synonyms: Arvicola stracheyi Thomas, 1880

Microtus cricetulus Miller, 1899

Alticola bhatnagari Biswas \& Khajuria, 1955

Subspecies: None

Distribution: Jammu \& Kashmir, Himachal Pradesh, and Sikkim in India, and Nepal.

Comments: Schwarz (1939) and Ellerman (1961) included this species under Alticola stoliczkanus (Blanford, 1875). Feng et al. (1986) reinstated it as a species (Musser \& Carleton, 1993). Biswas and Khajuria (1955) described new species of Alticola, named Bhatnagar's Vole Alticola bhatnagari Biswas \& Khajuria, 1955 from type specimen collected from Mingbo, Lanmoche Valley, Khumbu, Nepal. Agrawal (2000) synonymized this species with Alticola stracheyi (Thomas, 1880) based on their similarities in body colour and measurements.

\section{Genus Ellobius Fischer, 1814 Mole-voles}

This genus belongs to the subfamily Arvicolinae and is represented by a single species in the region (Ellerman, 1961; Corbet \& Hill, 1992).

\section{Ellobius fuscocapillus (Blyth, 1842)}

1842. Georhychus fuscocapillus Blyth, J. Asiatic Soc. Beng., 10: 928. [nom. nud. 1843, J. Asiatic Soc. Beng., 11: 887]

Name: Afghan Mole-vole

Type locality: Quetta, Baluchistan, Pakistan

Synonyms: Georhychus fuscocapillus Blyth, 1842

Subspecies: None

Distribution: Pakistan

Comments: Refer Roberts (1997) for morphological details.

\section{Genus Eothenomys Miller, 1896 \\ Voles}

This genus belongs to the subfamily Arvicolinae and is represented by a single species in the region (Ellerman, 1961; Corbet \& Hill, 1992).

\section{Eothenomys melanogaster (Milne-Edwards, 1871)}

1871. Arvicola melanogaster Milne-Edwards, in David Nouv. Arch. Mus. Hist. Nat. Paris, Bull., 7: 93 (footnote).

Name: Pere David's Vole

Type locality: Moupin, W. Sichuan, China

Synonyms: Arvicola melanogaster Milne-Edwards, 1871

Subspecies: Eothenomys melanogaster libonotus Hinton, 1923 Distribution: Arunachal Pradesh in India.

Comments: Ellerman (1961) included two subspecies, namely Eothenomys melanogaster cachinus (Thomas, 1921) and Eothenomys melanogaster libonotus Hinton, 1923. The former subspecies is not of our interest as it is reported from Myanmar. Corbet and Hill (1992) and Agrawal (2000) include only the latter subspecies for India.

\section{Genus Hyperacrius Miller, 1896 Voles}

This genus belongs to the subfamily Arvicolinae and is represented by two species in the region (Ellerman, 1961; Corbet and Hill, 1992). Hyperacrius was proposed by Miller (1896) as a subgenus, Hinton (1926) raised it to generic level. Both the species are endemic to the region.

\section{Hyperacrius fertilis (True, 1894)}

1894. Arvicola fertilis True, Proc. U.S. nation. Mus., 17: 10.

Name: True's Vole

Type locality: Pir Panjal Mt., Jammu \& Kashmir, India

Synonyms: Arvicola fertilis True, 1894

Microtus (Hyperacrius) aitchisoni Miller, 1897

Microtus (Hyperacrius) brachelix Miller, 1899

Subspecies: Hyperacrius fertilis zygomaticus Phillips, 1969 Distribution: Endemic to the region. Jammu \& Kashmir in India, Pakistan-occupied-Kashmir and Pakistan.

Comments: Ellerman (1961) listed two subspecies, namely Hyperacrius fertilis fertilis (True, 1894) and Hyperacrius fertilis brachelix (Miller, 1899). Regarding Hyperacrius aitchisoni Miller (1897), Ellerman (1961) remarked that "it is most likely a race of fertilis, but might perhaps be a race of wynnei". Corbet and Hill (1992) however synonymized Hyperacrius aitchisoni (Miller, 1897) with Hyperacrius fertilis (True, 1894). Agrawal (2000) synonymized Microtus (Hyperacrius) brachelix (Miller, 1899) with Hyperacrius fertilis (True, 1894) and does not mention anything about Hyperacrius aitchisoni (Miller, 1897). See Phillips (1969) for further details.

\section{Hyperacrius wynnei (Blanford, 1881)}

1881. Arvicola wynnei Blanford, J. Asiatic Soc. Beng., 49(1880): 244-245.

Name: Murree Vole 
Type locality: Murree, Rawilpindi, Punjab, Pakistan

Synonyms: Arvicola wynnei Blanford, 1881

Subspecies: Hyperacrius wynnei traubi Phillips, 1969

Distribution: Endemic to the region. Pakistan-occupied-Kashmir and Pakistan.

Comments: Phillips (1969) restricts its range to N. Pakistan. However, Corbet and Hill (1992), and Agrawal (2000) opine that it also occurs in India based on Ellerman (1961) report of its presence from Sardalla in Kashmir.

\section{Genus Microtus Schrank, 1798 Field Voles}

This genus belongs to the subfamily Arvicolinae and is represented by three species in the region. Ellerman (1961) listed five species from the region. Corbet and Hill (1992) does not write in detail about the Microtus Schrank, 1798 species belonging to the subgenus Pitymys Mc.Murtrie, 1831. However, Musser and Carleton (1993) has synonymized Pitymys Mc.Murtrie, 1831 with Microtus Schrank, 1798, a trend that we have followed here.

\section{Microtus juldaschi (Severtzov, 1879)}

1879. Neodon juldaschi Severtzov, Sap. Turk. Otd. Obsh. Lubit. Estestv., 1: 63.

Name: Juniper Vole

Type locality: near Aksu, Karakul Lake basin, Kirghizia

Synonyms: Neodon juldaschi Severtzov, 1879

Pitymys juldaschi (Severtzov, 1879)

Microtus carruthersi Thomas, 1909

Subspecies: None

Pitymys carruthersi (Thomas, 1909)

Distribution: North Pakistan, and probably in Pakistanoccupied-Kashmir (Musser \& Carleton, 1993).

Comments: It belongs to subgenus Neodon Hodgson, 1849. The status of the distinctive Microtus carruthersi Thomas, 1909 is unresolved (Musser \& Carleton, 1993). This form was treated by some as a separate species (Ellerman and MorrisonScott, 1951), while by others as a synonym of Microtus juldaschi (Severtzov, 1879) (Corbet, 1978). At present, following Musser and Carleton (1993), we include Microtus carruthersi Thomas, 1909 under Microtus juldaschi (Severtzov, 1879) with a question.

\section{Microtus leucurus (Blyth, 1863)}

1863. Phaiomys leucurus Blyth, J. Asiatic Soc. Beng., 32: 89.

Name: Blyth's Vole

Type locality: Lake Chomoriri (Tsomoriri), Ladakh, India

Synonyms: Phaiomys leucurus Blyth, 1863

Arvicola blythi Blanford, 1875

Microtus (Phaiomys) waltoni petulans Wroughton, 1911

Pitymys leucurus petulans (Wroughton, 1911)

Phaiomys everesti Thomas \& Hinton, 1922

Pitymys leucurus everesti (Thomas \& Hinton, 1922)

Subspecies: Microtus leucurus leucurus (Blyth, 1863)
Distribution: Jammu \& Kashmir, and Himachal Pradesh in India, and Nepal.

Comments: Ellerman (1961) included this species under subgenus Phiaomys Blyth, 1863, and listed three subspecies Pitymys leucurus leucurus (Blyth, 1863), Pitymys leucurus petulans (Wroughton, 1911), and Pitymys leucurus everesti (Thomas \& Hinton, 1922). Agrawal (2000) synonymized all the subspecies under the nominate species.

\section{Microtus sikimensis (Hodgson, 1849)}

1849. Neodon sikimensis Hodgson, Ann. Mag. nat. Hist., (2)3: 203.

Name: Sikkim Vole

Type locality: Sikkim, India

Synonyms: Neodon sikimensis Hodgson, 1849

$$
\text { Arvicola thricolis Gray, } 1863
$$

\section{Subspecies: None}

Distribution: Sikkim and West Bengal in India, Bhutan and Nepal (Biswas \& Khajuria, 1957; Abe, 1971).

Comments: Ellerman (1961) included this under subgenus Neodon Hodgson, 1849.

\section{Subfamily: Calomyscinae Genus Calomyscus Schrank, 1798 Mouse-like Hamsters}

This genus belongs to the subfamily Calomyscinae and is represented by two species in the region. Ellerman (1961) and Corbet and Hill (1992) listed this genus under subfamily Cricetinae. Musser and Carleton (1993) referring Vorontsov and Potapova (1979), and Carleton and Musser (1989) remark that the combination of distinctive features set these forms apart from the old world hamsters and close to cricetodontines, a group hitherto supposed extinct. Thus, to accommodate them, Vorontsov and Potapova (1979) erected subfamily Calomyscinae. Ellerman and Morrison-Scott (1951) considered this genus as monotypic, while Vorontsov et al. (1979) treated most of the subspecies of Calomyscus bailwardi Thomas, 1905 as distinct species. Commenting on this Musser and Carleton (1993) opine that this arrangement "should be tested with additional data". However, Corbet and Hill (1992) listed baluchi including hotsoni as subspecies of Calomyscus bailwardi Thomas, 1905. Presently, after Musser and Carleton (1993), Calomyscus bailwardi Thomas, 1905 is distributed in Iran and is not found in South Asian region.

\section{Calomyscus baluchi Thomas, 1920}

1920. Calomyscus baluchi Thomas, J. Bombay nat. Hist. Soc., 26:939.

Name: Baluchi Mouse-like Hamster

Type locality: Jelat (or Kelat) dist., Baluchistan, Pakistan

Synonyms: Calomyscus mustersi Ellerman, 1948

Subspecies: None

Distribution: Baluchistan in Pakistan.

Comments: Ellerman (1961) synonymized Calomyscus baluchi Thomas, 1920 with Calomyscus bailwardi bailwardi Thomas, 
1905 a trend also followed by Corbet and Hill (1992) who treated baluchi as a subspecies of Calomyscus bailwardi Thomas, 1905. Musser and Carleton (1993) quoting Vorontsov et al. (1979) remark that Calomyscus baluchi Thomas, 1920 includes mustersi (full name Calomyscus mustersi Ellerman, 1948), that was earlier treated as subspecies of Calomyscus bailwardi Thomas, 1905 by Corbet and Hill (1992). Wilson and Reeder (1993) consider this as a distinct species.

\section{Calomyscus hotsoni Thomas, 1920}

1920. Calomyscus hotsoni Thomas, J. Bombay nat. Hist. Soc., 26:938.

Name: Hotson's Mouse-like Hamster

Type locality: Gwambuk Kaul, 50km SW Pangjur (26³0'N, 63050'E), Baluchistan, Pakistan

Synonyms: Calomyscus bailwardi hotsoni (Thomas, 1920)

Subspecies: None

Distribution: Endemic to Pakistan. Baluchistan in Pakistan.

Comments: Ellerman (1961) synonymized Calomyscus hotsoni Thomas, 1920 with Calomyscus bailwardi hotsoni (Thomas, 1920). Corbet and Hill (1992) synonymized hotsoni with baluchi and treated the latter as a subspecies of Calomyscus bailwardi Thomas, 1905. Musser and Carleton (1993) quoting Vorontsov et al. (1979), and WIlson and Reeder (1993) recognize this as a distinct species and comment that it is known only from vicinity of type locality.

\section{Subfamily: Cricetinae Genus Cricetulus Milne-Edwards, 1871 Dwarf Hamsters}

This genus belongs to the subfamily Cricetinae and is represented by two species in the region (Ellerman, 1961; Corbet and Hill, 1992).

\section{Cricetulus alticola Thomas, 1917}

1917. Cricetulus alticola Thomas, Ann. Mag. nat. Hist., (8)19: 455.

Name: Ladakh Hamster

Type locality: Shushul, Ladakh, Jammu \& Kashmir, India

Synonyms: Cricetulus alticola tibetanus Thomas \& Hinton, 1922

Subspecies: None

Distribution: Ladakh in India, and Nepal.

Comments: Ellerman (1961) synonymized the Tibetan race with the nominate Cricetulus alticola Thomas, 1917, about which Agrawal (2000) offers no comments. Feng et al. (1986) considered it a subspecies of Cricetulus kamensis (Satunin, 1903) which Ellerman and Morrison-Scott (1951) treated as incertae sedis. Corbet and Hill (1992), and Musser and Carleton (1993) treated it as a distinct species. However, Corbet and Hill (1992) do not write anything in detail about this taxon since their work is restricted to species reported from Indomalayan region only.
18. Cricetulus migratorius (Pallas, 1773)

1773. Mus migratorius Pallas, Reise Prov. Russ. Reichs., 2: 703.

Name: Little Grey Hamster

Type locality: Lower Ural river, W. Kazakhstan

Synonyms: Mus migratorius Pallas, 1773

Cricetus (Cricetulus) fulvus Blanford, 1875

Subspecies: Cricetulus migratorius migratorius (Pallas, 1773)

Cricetulus migratorius cinerascens

(Wagner, 1848)

Cricetulus migratorius fulvus (Blanford, 1875)

Distribution: Jammu \& Kashmir in India, Pakistan-occupiedKashmir and Pakistan.

Comments: Ellerman (1961) listed two subspecies occurring from the region, while Corbet and Hill (1992) do not mention anything about the same. Ellerman and Morrison-Scott (1951) list Cricetulus migratorius cinerascens (Wagner, 1848) from Pakistan. Agrawal (2000) remarks that the subspecies listed by Ellerman (1961) resemble closely, hence do not warrant subspecific separation, but lists one subspecies Cricetulus migratorius fulvus (Blanford, 1875) occurring in the Indian range!

\section{Subfamily: Gerbillinae \\ Genus Gerbillus Desmarest, 1804 Gerbils}

This genus belongs to the subfamily Gerbillinae and is represented by four species in the region (Corbet and Hill, 1992). Ellerman (1961) included three species under two subgenera, Dipodillus Lataste, 1881 and Gerbillus Desmarest, 1804.

19. Gerbillus aquilus Schlitter \& Stezer, 1972

1972. Gerbillus aquilus Schlitter \& Stezer, Proc. Biol. Soc. Washington, 86: 167.

Name: Swarthy Gerbil

Type locality: $60 \mathrm{~km} \mathrm{~W}$ of Kerman, Iran

Synonyms: None

Subspecies: None

Distribution: Baluchistan in Pakistan.

Comments: It is included in subgenus Gerbillus Desmarest, 1804. Lay and Nadler (1975) and Lay (1983) treated Gerbillus aquilus Schlitter \& Stezer, 1972 separate from Gerbillus cheesmani Thomas, 1919, but Corbet and Hill (1992) considered it a subspecies of the latter. Musser and Carleton (1993) treat it distinct too.

\section{Gerbillus cheesmani Thomas, 1919}

1919. Gerbillus cheesmani Thomas, J. Bombay nat. Hist. Soc., 26: 748 .

Name: Cheesman's Gerbil

Type locality: near Basra, Lower Euphrates, Iraq

Synonyms: None

Subspecies: None

Distribution: Baluchistan in Pakistan.

Comments: It is included in subgenus Gerbillus Desmarest, 1804. Ellerman (1961) gives nothing more than a passing reference of this species. Musser and Carleton (1993) do not 
record it from the region but treat it as a distinct species and mention that Lay and Nadler (1975); Lay (1983); and Harrison and Bates (1991) reviewed this species.

\section{Gerbillus gleadowi Murray, 1886}

1886. Gerbillus gleadowi Murray, Ann. Mag. nat. Hist., (5)17: 246.

Name: Little Hairy-footed Gerbil

Type locality: Beruto, 15 miles SW of Rehti, Rohri dist., Sind, Pakistan

Synonyms: None

Subspecies: None

Distribution: Endemic to the region. Rajasthan, Gujarat in India, and Pakistan.

Comments: Ellerman (1961) includes this species under the subgenus Gerbillus Desmarest, 1804.

\section{Gerbillus nanus Blanford, 1875}

1875. Gerbillus nanus Blanford, Ann. Mag. nat. Hist., (4)16: 312.

Name: Baluchistan Gerbil

Type locality: Gedrosia, Baluchistan, Pakistan

Synonyms: Dipodillus indus Thomas, 1920

Subspecies: Gerbillus nanus nanus Blanford, 1875

Distribution: Rajasthan and Gujarat in India, and Pakistan.

Comments: Ellerman (1961) include Dipodillus indus Thomas, 1920 as subspecies of Gerbillus dasyurus (Wagner, 1842).

Subsequently after Harrison (1972), the Dipodillus indus Thomas, 1920 has been synonymized with Gerbillus nanus Blanford, 1875. Agrawal (2000) opines that the nominate species occurs in the region.

\section{Genus Meriones Illiger, 1811 Jirds, Sand Rats}

This genus belongs to the subfamily Gerbillinae and is represented by four species in the region (Corbet \& Hill, 1992). Ellerman (1961) included four species under three subgenera, Cheliones Thomas, 1919, Parameriones Heptner, 1937, and Pallasiomys Heptner, 1933.

\section{Meriones crassus Sundevall, 1842}

1842. Meriones crassus Sundevall, K. Svenska Vetensk. Akad. Handl., Ser 3: 233.

Name: Sundevall's Jird

Type locality: Ain Musa, Sinai, Egypt

Synonyms: Gerbillus swinhoei Scully, 1881

Meriones crassus swinhoei (Scully, 1881)

Subspecies: Meriones crassus crassus Sundevall, 1842

Distribution: Pakistan.

Comments: Ellerman (1961) included this species in subgenus Pallasiomys Heptner, 1933, and listed one subspecies Meriones crassus swinhoei (Scully, 1881) from the region. Corbet and Hill (1992) synonymized Gerbillus swinhoei Scully, 1881 with Meriones crassus Sundevall, 1842 following observations made by Koffler (1972).

\section{Meriones hurrianae (Jerdon, 1867)}

1867. Gerbillus hurrianae Jerdon, Mamm. India, 186.

Name: Indian Desert Gerbil

Type locality: Hissar, Haryana, India

Synonyms: Gerbillus hurrianae Jerdon, 1867

Cheliones hurrianae collinus Thomas, 1919

Subspecies: None

Distribution: Haryana, Rajasthan and Gujarat in India, and Pakistan.

Comments: Ellerman (1961) included this species in subgenus Cheliones Thomas, 1919. Roberts (1997) reviewed the Pakistan population.

\section{Meriones libycus Lichtenstein, 1823}

1823. Meriones libycus Lichtenstein, Verz. Doubl. Zool. Mus. Univ. Berlin, 5.

Name: Libyan Jird

Type locality: near Alexandria, Egypt

Synonyms: Gerbillus erythrourus Gray, 1842

Subspecies: None

Meriones libycus eryhrourus (Gray, 1842)

Distribution: Pakistan.

Comments: Ellerman (1961) included this species in subgenus Pallasiomys Heptner, 1933, and listed one subspecies Meriones libycus erythrourus (Gray, 1842) - the Afghan Jird, from this region. Corbet and Hill (1992) synonymize Gerbillus erythrourus Gray, 1842 with Meriones libycus Lichtenstein, 1823. Musser and Carleton (1993) provide a detailed remark on different works on this species.

\section{Meriones persicus (Blanford, 1875)}

1875. Gerbillus persicus Blanford, Ann. Mag. nat. Hist., (4)16: 312.

Name: Persian Jird

Type locality: Kohrud, 150 miles N of Isfahan, Iran

Synonyms: Gerbillus persicus Blanford, 1875

Subspecies: Meriones persicus persicus Blanford, 1875, Meriones persicus baptistae Thomas, 1920

Distribution: Pakistan.

Comments: Ellerman (1961) included this species in subgenus Parameriones Heptner, 1937, and listed two subspecies Meriones persicus persicus Blanford, 1875 and Meriones persicus baptistae Thomas, 1920. Roberts (1997) reviewed the Pakistan population.

\section{Genus Rhombomys Wagner, 1841 Great Gerbil}

This genus belongs to the subfamily Gerbillinae and is represented by a single species in the region (Corbet \& Hill, 1992). Ellerman (1961) does not include this in his account.

\section{Rhombomys opimus (Lichtenstein, 1823)}

1823. Meriones opimus Lichtenstein, Naturh. Abh. Eversmann's Reise, 122.

Name: Great Gerbil 
Type locality: between Orenburg and Bukhara, Uzbekistan

Synonyms: Meriones opimus Lichtenstein, 1823

Subspecies: None

Distribution: Pakistan.

Comments: Roberts (1997) reviewed the Pakistan population. Corbet and Hill (1992) inform that it occurs along the western border of Pakistan, and also provide in brief the characteristic features of the genus.

\section{Genus Tatera Lataste, 1882 Large Gerbils}

This genus belongs to the subfamily Gerbillinae and is represented by a single species in the region (Corbet \& Hill, 1992).

\section{Tatera indica (Hardwicke, 1807)}

1807. Dipus indicus Hardwicke, Trans. Linn. Soc. London, 8: 279.

Name: Indian Gerbil (Antelope Rat)

Type locality: between Benaras (Varnasi) and Hardwar, Uttar Pradesh, India

Synonyms: Dipus indicus Hardwicke, 1807

Gerbillus otarius Cuvier, 1838

Gerbillus cuvieri Waterhouse, 1838

Gerbillus hardwickei Gray, 1843

Tatera indica hardwickei (Gray, 1843)

Tatera ceylonica Wroughton, 1906

Tatera indica ceylonica (Wroughton, 1906)

Tatera sherrini Wroughton, 1917

Tatera dunni Wroughton, 1917

Subspecies: Tatera indica indica (Hardwicke, 1807)

Tatera indica cuvieri (Waterhouse, 1838)

Distribution: Jammu \& Kashmir, Himachal Pradesh, Punjab, Haryana, Rajasthan, Gujarat, Madhya Pradesh, Chattisgarh, Maharashtra, Uttar Pradesh, Uttaranchal, Bihar, Jharkhand, West Bengal, Goa, Karnataka, Andhra Pradesh, Tamil Nadu and Kerala in India; Pakistan; Nepal; and Sri Lanka.

Comments: Ellerman (1961) listed four subspecies Tatera indica indica (Hardwicke, 1807), Tatera indica hardwickei (Gray, 1843), Tatera indica ceylonica (Wroughton, 1906), and Tatera indica cuvieri (Waterhouse, 1838) from the region. Agrawal and Chakraborty (1981); Bates (1988); Corbet and Hill (1992); and Agrawal (2000) list only two valid subspecies Tatera indica indica (Hardwicke, 1807) and Tatera indica cuvieri (Waterhouse, 1838) from this region.

\section{Subfamily: Murinae \\ Genus Acomys Geoffroy, 1838 Spiny Mice}

This genus belongs to subfamily Murinae. Only one species occurs in South Asia (Ellerman, 1961; Corbet \& Hill, 1992).

29. Acomys dimidiatus (Cretzschmar, 1826)

1826. Mus dimidiatus Cretzschmar, in Rüppel, Atlas zu der Reise im Nördliche Africa, Saugeth. 13: 37

Name: Arabian Spiny Mouse

Type locality: Sinai, Egypt

Synonyms: Mus dimidiatus Cretzschmar, 1826 Acomys flavidus Thomas, 1917

\section{Subspecies: None}

Distribution: Pakistan.

Comments: Much confusion has arisen over the specific identity of species within the Acomys cahirinus - dimidiatus complex. Ellerman (1961) remarked that Acomys cahirinus flavidus (Thomas, 1917) was not distinguishable from Acomys dimidiatus (Cretzschmar, 1826). Musser and Carleton (1993) opined that the cahirinus - dimidiatus complex needed critical systematic revision. However, recently, Denys et al. (1994) cited dental characters to clearly separate a number of species within the complex including Acomys dimidiatus (Cretzschmar, 1826). Hence Acomys dimidiatus (Cretzschmar, 1826), here, has been considered as a valid species. Distribution in Pakistan was reviewed by Bates (1994) under Acomys cahirinus (Desmarest, 1819).

\section{Genus Apodemus Kaup, 1829 \\ Palaearctic Wood Mice}

This genus belongs to subfamily Murinae. Currently there are five species recognized from South Asia. One species is endemic to Nepal (Gemmeke \& Niethammer, 1982). All the species belong to subgenus Sylvaemus Ognev, 1924. Earlier all the forms were referred under two species, namely, Apodemus sylvaticus (Linnaeus, 1758) and Apodemus flavicollis (Melchoir, 1834) (Ellerman, 1961). Apodemus flavicollis (Melchoir, 1834) - an European species, is not a valid species for the region.

\section{Apodemus draco (Barrett-Hamilton, 1900)}

1900. Mus sylvaticus draco Barrett-Hamilton, Proc. zool. Soc. London, 1900: 418.

Name: South China Wood Mouse

Type locality: Kuatan, NW Fujian, S China

Synonyms: Mus sylvaticus draco Barrett-Hamilton, 1900

Apodemus sylvaticus draco (Barrett-Hamilton, 1900)

\section{Subspecies: None}

Distribution: Arunachal Pradesh (Corbet \& Hill, 1992) and Assam (Musser \& Carleton, 1993), India.

Comments: Ellerman and Morrison-Scott (1951), and Ellerman (1961) treated it as a subspecies of Apodemus sylvaticus (Linnaeus, 1758). Ellerman (1941); Corbet (1978); and Corbet and Hill $(1991,1992)$ treated it as distinct species.

\section{Apodemus gurkha Thomas, 1924}

1924. Apodemus gurkha Thomas, J. Bombay nat. Hist. Soc., 29(4): 888.

Name: Himalayan Wood Mouse

Type locality: Laprak, Gorkha, Nepal

Synonyms: Apodemus flavicollis gurkha (Thomas, 1924) 
Subspecies: None

Distribution: Endemic to Nepal, restricted in distribution to Central Nepal.

Comments: Ellerman and Morrison-Scott (1951), and Ellerman (1961) considered it as a subspecies of Apodemus flavicollis (Melchior, 1834). Corbet and Hill (1992); Musser and Carleton (1993); and Agrawal (2000) considered it a distinct species.

\section{Apodemus latronum (Thomas, 1911)}

1911. Apodemus speciosus latronum Thomas, Abstr. Proc. zool. Soc. London, 100: 49; Proc. zool. Soc. London, 1912: 137.

Name: Sichuan Field Mouse

Type locality: Tatsienlu, W Szechwan, China

Synonyms: Apodemus speciosus latronum Thomas, 1911

Apodemus flavicollis latronum (Thomas, 1911)

Subspecies: None

Distribution: Arunachal Pradesh, India (Corbet \& Hill, 1992).

Comments: Ellerman and Morrison-Scott (1951), and Ellerman (1961) considered it as a subspecies of Apodemus flavicollis (Melchoir, 1834). Feng et al. (1986) treated it as a subspecies of Apodemus draco (Barrett-Hamilton, 1900). Corbet (1978), and Corbet and Hill (1992) considered it as a distinct species.

\section{Apodemus orestes (Thomas, 1911)}

1911. Apodemus speciosus orestes Thomas, Abstr. Proc. zool. Soc. London, 100: 49; Proc. zool. Soc. London, 1912: 136.

Name: Chinese Wood Mouse

Type locality: Mt. Omei Shan, Szechwan, China

Synonyms: Apodemus speciosus orestes Thomas, 1911 Apodemus sylvaticus orestes (Thomas, 1911)

Subspecies: None

Distribution: Arunachal Pradesh, India (Corbet \& Hill, 1992; Agrawal, 2000).

Comments: Ellerman (1961) treated Apodemus orestes (Thomas, 1911) as a subspecies of Apodemus sylvaticus (Linnaeus, 1758). Musser and Carleton (1993) synonymized this species with Apodemus draco (Barrett-Hamilton, 1900). However, Corbet and Hill (1992), and Agrawal (2000) treated it as a distinct species.

\section{Apodemus sylvaticus (Linnaeus, 1758)}

1758. Mus sylvaticus Linnaeus, Syst. Nat., 10 ${ }^{\text {th }}$ ed., 1: 62.

Name: Wood Mouse

Type locality: Uppsala, Sweden

Synonyms: Mus sylvaticus Linnaeus, 1758

Mus arianus griseus True, 1894

Micromys sylvaticus pentax Wroughton, 1908

Apodemus sylvaticus pentax (Wroughton, 1908)

Apodemus flavicollis rusiges Miller, 1913

Subspecies: Apodemus sylvaticus wardi (Wroughton, 1908)

Distribution: Nepal; Jammu \& Kashmir, Himachal Pradesh, Haryana, and Uttaranchal in India; and Pakistan.

Comments: Ellerman (1961) included two subspecies, namely Apodemus sylvaticus pentax (Wroughton, 1908) from Pakistan and Apodemus sylvaticus orestes (Thomas, 1911) from China under this species. Agrawal (2000) lists only one subspecies, namely Apodemus sylvaticus wardi (Wroughton, 1908) and synonymised Apodemus flavicollis rusiges Miller, 1913 and Apodemus sylvaticus pentax (Wroughton, 1908) with this taxon based on overlapping morphometry and pelage colouration. Musser and Carleton (1993) treated Apodemus orestes (Thomas, 1911)as a synonym of Apodemus draco (Barrett-Hamilton, 1900), and considered Apodemus sylvaticus wardi (Wroughton, 1908) and Apodemus flavicollis rusiges Miller, 1913 as distinct species by themselves. However, we synonymized Apodemus flavicollis rusiges Miller, 1913 and included Apodemus sylvaticus wardi (Wroughton, 1908) as subspecies of Apodemus sylvaticus (Linnaeus, 1758) following Corbet and Hill (1992), and Agrawal (2000). Agrawal (2000) has provided detailed account based on fairly large sample size deposited in Zoological Survey of India collection before concluding on the taxonomic status of the subspecies and species.

\section{Genus Bandicota Gray, 1873 Bandicoot-rats}

This genus belongs to subfamily Murinae. Currently there are three species recognized from South Asia.

\section{Bandicota bengalensis (Gray \& Hardwicke, 1833)}

1833. Arvicola bengalensis Gray (in Hardwicke, 1830-35), Illustr. Indian Zool., 2: pl. 21.

Name: Lesser Bandicoot-rat

Type locality: Bengal, India

Synonyms: Arvicola bengalensis Gray \& Hardwicke, 1833 Mus kok Gray, 1837

Mus (Neotoma) providens Elliot, 1839

Mus dubius Kelaart, 1850

Mus deccaensis Tytler, 1854

Mus tarayensis Horsfield, 1855

Mus plurimammis Horsfield, 1855

Mus morungensis Horsfield, 1855

Mus (Nesokia) blythianus Anderson, 1878

Mus (Nesokia) barclayanus Anderson, 1878

Nesokia gracilis Nehring, 1902

Gunomys varius Thomas, 1907

Gunomys varillus Thomas, 1907

Gunomys lordi Wroughton, 1908

Gunomys sindicus Wroughton, 1908

Gunomys kok insularis Phillips, 1936

Subspecies: Bandicota bengalensis bengalensis (Gray \&

Hardwicke, 1833)

Bandicota bengalensis wardi (Wroughton, 1908)

Distribution: Almost throughout India; Pakistan; Nepal; Bangladesh.

Comments: Ellerman and Morrison-Scott (1951), and Ellerman (1961) listed five subspecies, namely, Bandicota bengalensis bengalensis (Gray \& Hardwicke, 1833), Bandicota bengalensis kok (Gray, 1837), Bandicota bengalensis gracilis (Nehring, 1902), Bandicota bengalensis varius (Thomas, 1907), and Bandicota bengalensis wardi (Wroughton, 1908). Corbet and 
Hill (1992) quoting Agrawal and Chakraborty (1976) included three subspecies from the Indo-Malayan region. For South Asia, only two subspecies, namely - Bandicota bengalensis bengalensis (Gray, 1835) and Bandicota bengalensis wardi (Wroughton, 1908) are valid. The latter subspecies is restricted in distribution to the Himalayan tracts of Jammu \& Kashmir and Himachal Pradesh (Agrawal, 2000). Pradhan (1979) and Pradhan et al. (Comm.) have doubted the inclusion of kok and lordi populations in Bandicota bengalensis (Gray \& Hardwicke, 1833) on the basis of morphological, osteomorphological and biochemical studies.

\section{Bandicota indica (Bechstein, 1800)}

1800. Mus indicus Bechstein, In Pennant, Allgemeine Ueber Vierf. Thiere., 2: 497.

Name: Large Bandicoot-rat

Type locality: Pondicherry, India

Synonyms: Mus indicus Bechstein, 1800

? Mus bandicota Bechstein, 1800

Mus malabarica Shaw, 1801

Mus perchal Shaw, 1801

Mus (Rattus) nemorivagus Hodgson, 1836

Mus macropus Hodgson, 1845

Mus (Nesokia) elliotanus Anderson, 1878

Subspecies: Bandicota indica indica (Bechstein, 1800)

Bandicota indica nemorivaga (Hodgson, 1836)

Bandicota indica malabarica (Shaw, 1801)

Distribution: India; Pakistan; Nepal; Bangladesh; Sri Lanka.

Comments: Ellerman (1961) listed three subspecies. Chakraborty and Chakraborty (1991), and Agrawal (2000) recognize two subspecies, namely - Bandicota indica indica (Bechstein, 1800) and Bandicota indica nemorivaga (Hodgson, 1836). The former subspecies is widespread including most of India, Pakistan, and Sri Lanka, while the latter subspecies is restricted in distribution to Nepal; Bangladesh and northeastern India including West Bengal, Meghalaya, Assam, and Manipur. However, Pradhan et al. (1993) while revising genus Bandicota, have reported third valid subspecies from Western Ghats in addition to the above mentioned two subspecies. Bandicota indica malabarica (Shaw, 1801) is restricted to, but, is widespread in distribution in the Western Ghats. The revisionary studies of genus Bandicota reported by Pradhan et al. (1993) and Pradhan et al. (Comm.) are based on the latest and widely accepted morpho/osteo-taxonomical, biochemtaxonomical, genetical and hair pattern analytical.techniques.

\section{Bandicota maxima Pradhan et al., 1993}

1993. Bandicota maxima Pradhan et al., Rec. Zool. Surv. India, 93(1,2): 175-200.

Name: Large Bandicoot-rat

Type locality: Nanapeth, Pune, India

Synonyms: Mus giganteus Hardwicke, 1804

Subspecies: None

Distribution: India; Nepal; Bangladesh.
Comments: Pradhan et al. (1989) proposed the population of the large-sized bandicoot rats from India as Bandicota gigantea non Hardwicke, which was not accepted by Corbet and Hill (1992). Later detailed revisionary studies of genus Bandicota reported by Pradhan et al. (1993) resulted in describing a new species, Bandicota maxima Pradhan et al., 1993. But, while raising some doubts, Agrawal (2000) again tentatively kept Bandicota maxima Pradhan et al., 1993 in Bandicota indica (Bechstein, 1800). However, the studies reported by Pradhan et al. (1993) were based on the latest and widely accepted morpho/osteo-taxonomical, biochem-taxonomical, genetical and hair pattern analytical techniques carried out on freshly collected adult specimens. While following the available keys they found it, rather, impossible at that time to merge the population of large sized bandicoot rats in Bandicota indica (Bechstein, 1800) due to distinct differences in number of key characters and treated it as distinct species. On the basis of the observations made by Pradhan et al. (1993) and Pradhan et al. (Comm.), we are retaining Bandicota maxima Pradhan et al., 1993. For further details see Pradhan et al. (1993).

\section{Genus Berylmys Ellerman, 1947 Rats}

This genus belongs to subfamily Murinae. Earlier included as a subgenus under the genus Rattus Fischer, 1803. The species belonging to this genus were earlier listed under subgenera Berylmys [Rattus (Berylmys) manipulus (Thomas, 1916) and Rattus (Berylmys) berdmorei (Blyth, 1851)] and Stenomys [Rattus (Stenomys) bowersi (Anderson, 1879) including the subspecies Rattus (Stenomys) bowersi mackenziei (Thomas, 1916)]. Currently there are three species recognized from South Asia.

\section{Berylmys bowersi (Anderson, 1879)}

1879. Mus bowersii Anderson, Anat. Zool. Res. Yunnan, 304.

Name: Bower's Rat

Type locality: Hotha, Kakhyen Hills, Yunnan, China

Synonyms: Mus bowersii Anderson, 1879

Rattus bowersi (Anderson, 1879)

Subspecies: Berylmys bowersi bowersi (Anderson, 1879)

Distribution: Arunachal Pradesh, Meghalaya, Nagaland, Mizoram, and Manipur in India.

Comments: Ellerman (1961) included this species under Rattus (Stenomys) bowersi (Anderson, 1879) and included three subspecies, namely Rattus bowersi bowersi (Anderson, 1879); Rattus bowersi mackenziei (Thomas, 1916) and Rattus bowersi feae (Thomas, 1916). Later, Musser and Newcomb (1983) revised the species belonging to subgenera of Rattus Fischer, 1803 and proposed Berylmys genus as consisting of four species from the Indo-Malayan region, namely Berylmys manipulus (Thomas, 1916); Berylmys berdmorei (Blyth, 1851); Berylmys mackenziei (Thomas, 1916) and Berylmys bowersi (Anderson, 1879). Corbet and Hill (1992), and Agrawal (2000) also followed this scheme. 


\section{Berylmys mackenziei (Thomas, 1916)}

1916. Epimys mackenziei Thomas, J. Bombay nat. Hist. Soc., 24(3): 410.

Name: Mackenzie's Rat

Type locality: 50 miles west of Kindat, Chin Hills, Burma (now Myanmar)

Synonyms: Epimys mackenziei Thomas, 1916

Rattus wellsi Thomas, 1921

Subspecies: None

Distribution: Arunachal Pradesh, Meghalaya, Nagaland, Mizoram, and Manipur in India.

Comments: Ellerman (1961) included this as a subspecies of Rattus (Stenomys) bowersi (Anderson, 1879). Later, following revision by Musser and Newcomb (1983) it was upgraded to species status (Corbet \& Hill, 1992). Agrawal (2000) also considers it to be a distinct species.

\section{Berylmys manipulus (Thomas, 1916)}

1916. Epimys manipulus Thomas, J. Bombay nat. Hist. Soc., 24(3): 413.

Name: Manipur Rat

Type locality: Kampat, 20 mile west of Kindat, Kabaw Valley, C. Myanmar (now Myanmar)

Synonyms: Epimys manipulus Thomas, 1916

Rattus manipulus kekrimus Roonwal, 1948

Subspecies: Berylmys manipulus manipulus (Thomas, 1916)

Distribution: Assam, Nagaland, and Manipur in India.

Comments: Ellerman (1961) included this under the subgenus Berylmys Ellerman, 1947, and included two subspecies, namely, Rattus manipulus manipulus (Thomas, 1916) and Rattus manipulus kekrimus Roonwal, 1948. Corbet and Hill (1992) also indicate this fact. However, Agrawal (2000) synonymized the latter with the former based on the marked morphometric and morphological similarities between the two taxa.

\section{Genus Chiropodomys Peters, 1868 Tree-Mouse}

This genus belongs to subfamily Murinae. Currently only one species is recognized from South Asia.

\section{Chiropodomys gliroides (Blyth, 1856)}

1856. Mus gliroides Blyth, J. Asiat. Soc. Beng., 24: 721.

Name: Pencillate-tailed Tree-mouse

Type locality: Cherrapunji, Khasi Hills, Meghalaya, India

Synonyms: Mus gliroides Blyth, 1856

Mus peguensis Blyth, 1859

Subspecies: Chiropodomys gliroides gliroides (Blyth, 1856)

Distribution: Meghalaya, and Manipur in India.

Comments: Of the five subspecies recognized, the nominate form occurs in the region(Ellerman, 1961; Musser, 1979; Agrawal, 2000).

\section{Genus Cremnomys Wroughton, 1912 \\ Rats}

This genus belongs to subfamily Murinae. Earlier included as a subgenus under the genus Rattus Fischer, 1803. The species belonging to this genus was earlier listed under subgenus Cremnomys Wroughton, 1912. Currently there are three species recognized from South Asia. One species is endemic to South Asia, while two are endemic to India.

\section{Cremnomys blanfordi (Thomas, 1881)}

1881. Mus blanfordi Thomas, Ann. Mag. nat. Hist., (5)7: 24.

Name: Blanford's Rat

Type locality: Kadapa (now Cuddapah), Madras (now Andhra Pradesh), India

Synonyms: Mus blanfordi Thomas, 1881

\section{Subspecies: None}

Distribution: Endemic to South Asia. Andhra Pradesh, Bihar, West Bengal, Chattisgarh, Madhya Pradesh, Orissa, Maharashtra, Karnataka, Goa, Kerala in India; and Sri Lanka.

Comments: Ellerman (1961) placed this species under the subgenus Rattus Fischer, 1803, while Misonne (1969) included it under subgenus Cremnomys Wroughton, 1912. Agrawal (2000) treated Cremnomys Wroughton, 1912 as genus, and reflected the views that it be treated as a genus by itself as suggested by Misonne (1969) and Mishra (1981) based on its morphology and lice fauna respectively.

\section{Cremnomys cutchicus Wroughton, 1912}

1912. Cremnomys cutchicus Wroughton, J. Bombay nat. Hist., 21:340.

Name: Cutch Rock Rat

Type locality: Dhonsa, Kutch, Gujarat, India

Synonyms: Rattus cutchicus (Wroughton, 1912)

Rattus cutchicus cutchicus (Wroughton, 1912)

Cremnomys medius Thomas, 1916

Rattus cutchicus medius (Thomas, 1916)

Cremnomys medius caenosa Thomas, 1916

Cremnomys medius caenosus Thomas, 1916

Cremnomys medius rajput Thomas, 1916

Rattus cutchicus rajput (Thomas, 1916)

Cremnomys australis Thomas, 1916

Rattus cutchicus australis (Thomas, 1916)

Cremnomys australis siva Thomas 1916

Rattus cutchicus siva (Thomas, 1916)

Cremnomys cutchicus leechi Harrison, 1974

Subspecies: None

Distribution: Endemic to India. Gujarat, Karnataka, Bihar, Orissa, Rajasthan in India.

Comments: Ellerman (1961) included this under subgenus Cremnomys Wroughton, 1912 and recognized five subspecies, namely - Rattus cutchicus cucthicus (Wroughton, 1912), Rattus cutchicus siva (Thomas, 1916), Rattus cutchicus australis (Thomas, 1916), Rattus cutchicus medius (Thomas, 1916), and Rattus cutchicus rajput (Thomas, 1916). Corbet and Hill (1992) 
list Cremnomys medius caenosus Thomas, 1916, Cremnomys medius rajput Thomas, 1916, Cremnomys australis siva Thomas, 1916, and Cremnomys cutchicus leechi Harrison, 1974. Agrawal (2000) considered all the subspecies listed by Ellerman (1961) not being different from one another based on studies carried out on the specimens present with Zoological Survey of India and Bombay Natural History Society and synonymized them with Cremnomys cutchicus Wroughton, 1912.

\section{Cremnomys elvira (Ellerman, 1947)}

1947. Rattus (Cremnomys) elvira Ellerman, Ann. Mag. nat. Hist., (11)13: 207.

Name: Large Rock Rat

Type locality: Kurumbpatti, Salem dist., Tamil Nadu, India

Synonyms: Rattus (Cremnomys) elvira Ellerman, 1947

Subspecies: None

Distribution: Endemic to India. Known only from type locality. Comments: Ellerman (1961) treated it under subgenus Cremnomys Wroughton, 1912. This is an endemic rat from Eastern Ghats of Tamil Nadu, India. Musser and Carleton (1993) remark that this species is "still represented by a few specimens from the region of the type locality".

\section{Genus Dacnomys Thomas, 1916 Large-toothed Rat}

This genus belongs to subfamily Murinae. Monotypic genus characterized by unusually large maxillary tooth rows. One species recognized from South Asia.

\section{Dacnomys millardi Thomas, 1916}

1916. Dacnomys millardi Thomas, J. Bombay nat. Hist. Soc., 24(3): 405.

Name: Millard's Rat

Type locality: Gopaldhara, near Darjeeling, West Bengal, India Synonyms: Dacnomys wroughtoni Thomas, 1922

Subspecies: Dacnomys millardi millardi Thomas, 1916

Dacnomys millardi wroughtoni Thomas, 1922

Distribution: West Bengal, Nagaland, Arunachal Pradesh in India; and Nepal.

Comments: Ellerman (1961) and Agrawal (2000) included two subspecies under this species. Musser (1981) reviewed this genus in detail.

\section{Genus Diomys Thomas, 1917}

This genus belongs to subfamily Murinae. Monotypic genus characterized by small body size and pro-odont incisors. One species recognized from South Asia.

\section{Diomys crumpi Thomas, 1917}

1917. Diomys crumpi Thomas, J. Bombay nat. Hist. Soc., 25: 204.

Name: Crump's Mouse

Type locality: Mt. Pasernath, Hazaribagh dist., Bihar (presently in Jharkhand), India

Synonyms: None
Subspecies: None

Distribution: Endemic to the region. Jharkhand, Manipur in India; and Nepal (Ingles et al., 1980).

Comments: Ellerman (1961) mentions about a series of skulls from Frost Collection, Manipur. Although, Musser and Newcomb (1983) report its occurrence from North Myanmar, we retain this taxon as regional endemic considering the population as 'spilled'.

\section{Genus Golunda Gray, 1837 Bush-Rats}

This genus belongs to subfamily Murinae. One species recognized from South Asia.

\section{Golunda ellioti Gray, 1837}

1837. Golunda ellioti Gray, Charlesworth's Mag. nat. Hist., 1: 586.

Name: Indian Bush-Rat

Type locality: Dharwar, Karnataka, India

Synonyms: Mus hirustus Elliot 1839

Mus myothrix Hodgson, 1845

Golunda ellioti myothrix (Hodgson, 1845)

? Golunda coffaeus Kelaart, 1850

Mus newara Kelaart, 1850

Mus nuwara Kelaart, 1850

Golunda ellioti nuwara (Kelaart, 1850)

Pelomys watsoni Blanford, 1876

Golunda ellioti watsoni (Blanford, 1876)

Golunda newara Blanford, 1891

Golunda ellioti paupera Thomas, 1923

Golunda ellioti gujerati Thomas, 1923

Golunda ellioti bombax Thomas, 1923

Golunda ellioti coraginis Thomas, 1923

Golunda ellioti coenosa Thomas, 1923

? Golunda ellioti limitaris Thomas, 1923

Subspecies: Golunda ellioti ellioti Gray, 1837

Golunda ellioti nuwara (Kelaart, 1850)

Distribution: Jammu \& Kashmir, Himachal Pradesh, Haryana, Uttaranchal, Rajasthan, Gujarat, Chattisgarh, Madhya Pradesh, Jharkhand, Orissa, Maharashtra, Andhra Pradesh, Karnataka, Tamil Nadu, West Bengal, Assam, in India; Sri Lanka; Pakistan, Nepal, Bhutan and Bangladesh.

Comments: Ellerman (1961) listed seven subspecies, namely Golunda ellioti ellioti Gray, 1837, Golunda ellioti gujerati Thomas, 1923, Golunda ellioti paupera Thomas, 1923, Golunda ellioti nuwara (Kelaart, 1850), Golunda ellioti myothrix (Hodgson, 1845), Golunda ellioti coenosa Thomas, 1923, and Golunda ellioti watsoni (Blanford, 1876). Ellerman (1961) also opined that "apart from nuwara, the races of this species are doubtful and others retained might just as well be placed in the synonymy of the typical form". Corbet and Hill (1992) listed three subspecies, namely Golunda ellioti ellioti Gray, 1837, Golunda ellioti gujerati Thomas, 1923, and Golunda ellioti nuwara (Kelaart, 1850), based on the review by Agrawal and 
Chakraborty (1982). However, Agrawal (2000) synonymized Golunda ellioti gujerati Thomas, 1923 with the nominate form Golunda ellioti ellioti Gray, 1837.

\section{Genus Hadromys Thomas, 1911 Bush Rat}

This genus belongs to subfamily Murinae. Monotypic genus characterized by concave anterior border of the zygomatic plate and broad upper incisors.

\section{Hadromys humei (Thomas, 1886)}

1886. Mus humei Thomas, Proc. zool. Soc. Lond., 1886: 63.

Name: Hume's Rat

Type locality: Moirang, Manipur, India

Synonyms: Mus humei Thomas, 1886

Subspecies: Hadromys humei humei (Thomas, 1886)

Distribution: Manipur, and Assam in India.

Comments: Corbet and Hill (1992) mention about Hadromys humei yunanensis Yang \& Wang, 1987 from West Yunnan.

\section{Genus Leopoldamys Ellerman, 1947 Long-tailed Giant Rats}

This genus belongs to subfamily Murinae. Earlier included under the genus Rattus Fischer, 1803. Leopoldamys was erected and treated as a subgenus of Rattus by Ellerman (1947). However, Musser (1981) treated it as a distinct genus. Currently there are two species recognized from South Asia.

\section{Leopoldamys edwardsi (Thomas, 1882)}

1882. Mus edwardsi Thomas, Proc. zool. Soc. Lond., 1882: 587. Name: Edward's Rat

Type locality: Kuatan (probably), Mtns of W Fujian, China Synonyms: Mus edwardsi Thomas, 1882

Epimys listeri Thomas, 1916

Epimys listeri garonum Thomas, 1921

Subspecies: Leopoldamys edwardsi edwardsi (Thomas, 1882) Distribution: West Bengal, Arunachal Pradesh, Meghalaya and Nagaland in India. Probably also in Bhutan.

Comments: Ellerman (1961) concluded that there is no significant variation in listeri and edwardsi and hence synonymised with the latter. Corbet and Hill (1992) recognize Rattus listeri garonum Thomas, 1921, while Agrawal (2000) synonymized it with type species. Musser and Carleton (1993) consider the species is in need of taxonomic revision and that samples from Indochina may represent a different species from those from the Malay Peninsula and Sumatra.

\section{Leopoldamys sabanus (Thomas, 1887)}

1887. Mus sabanus Thomas, Ann. Mag. nat. Hist., (5)20: 269.

Name: Noisy rat

Type locality: Gunung Kinabalu, Sabah (N Borneo), Malaysia Synonyms: Mus sabanus Thomas, 1887 (many from its range in SE Asia)

Subspecies: None

Distribution: Bangladesh.
Comments: Ellerman (1961) listed two subspecies, namely Rattus sabanus vociferans (Miller, 1900) and Rattus sabanus garonum (Thomas, 1921) [originally as Epimys listeri garonum Thomas, 1921]. Leopoldamys sabanus (Thomas, 1887) reported from Meghalaya is a misidentification of Leopoldamys edwardsi (Thomas, 1882), as such it does not occur in India (Musser, 1981; Agrawal, 2000). The latter subspecies listed by Ellerman (1961) is presently synonymized with Leopoldamys edwardsi (Thomas, 1882)

\section{Genus Micromys Dehne, 1841 Pygmy Mouse}

This genus belongs to subfamily Murinae. Monotypic genus characterized by small size and prehensile tail. One species recognized from South Asia.

\section{Micromys minutus (Pallas, 1771)}

1771. Mus minutus Pallas, Reise. Prov. Russ. Reichs., 1: 454.

Name: Harvest Mouse

Type locality: Simbrisk (now Ulyanousk), Ulyanousk, Russia

Synonyms: Mus minutus Pallas, 1771

Mus erythrotis Blyth, 1855

Mus pygmaeus Milne-Edwards, 1874

Subspecies: Micromys minutus erythrotis (Blyth, 1855)

Distribution: Meghalaya and Nagaland in India.

Comments: Ellerman (1961) and Agrawal (2000) recognize Micromys minutus erythrotis (Blyth, 1855) from India. Musser and Carleton (1993) consider that critical revision is required to determine whether this widespread species represents one or more species. Specimens from Asia are morphologically very distinct from European specimens (Mike Jordan, pers. comm.).

\section{Genus Millardia Thomas, 1911 Soft-furred Rats}

This genus belongs to subfamily Murinae. Ellerman (1961) treated Millardia as a subgenus under Rattus Fischer, 1803. But based on its unique characters it was raised to the generic level by Misonne (1969) and Agrawal (1970). Three species recognized from South Asia of which one species is endemic to India, while other two are endemic to the region.

\section{Millardia gleadowi (Murray, 1885)}

1885. Mus gleadowi Murray, Proc. zool. Soc. Lond., 1885: 809.

Name: Sand-coloured Metad

Type locality: Karachi, Sind, Pakistan

Synonyms: Mus gleadowi Murray, 1885

Subspecies: None

Distribution: Endemic to the region. Gujarat and Rajasthan in India, and Pakistan.

Comments: Possesses four plantar pads. Ellerman (1961) included this species under the genus Rattus Fischer, 1803.

\section{Millardia kondana Mishra \& Dhanda, 1975}

1975. Millardia kondana Mishra \& Dhanda, J. Mammal., 56: 76. 
Name: Large Metad

Type locality: Sinhgarh $\left(18^{0} 23^{\prime} \mathrm{N}, 73^{\circ} 42^{\prime} \mathrm{E}\right)$, Poona dist., Maharashtra, India

Synonyms: None

Subspecies: None

Distribution: Endemic to India. Known only from type locality. Comments: Large-sized metad unique in possessing six plantar pads. Corbet and Hill (1992) remark that "in describing $M$. kondana the authors did not mention the presence or absence of M. meltada in the same or adjacent localities, although the latter has been recorded from Pune and from Dharwar where they are of normal size, much smaller than M. kondana". One of the survey parties of ZSI, WRS, Pune, has also collected Millardia kondana Mishra \& Dhanda, 1975 from the type locality during a survey conducted in 1990.

\section{Millardia meltada (Gray, 1837)}

1837. Golunda meltada Gray, Charlesworth's Mag. nat. Hist., 1: 586.

Name: Soft-furred Metad

Type locality: Dharwar, S. Mahratta (now Karnataka), India

Synonyms: Golunda meltada Gray, 1837

Rattus meltada meltada (Gray, 1837)

Mus lanuginosus Elliot, 1839

Mus comberi Wroughton, 1907

Mus listoni Wroughton, 1907

Millardia meltada pallidor Ryley, 1914

Rattus meltada pallidor (Ryley, 1914)

Millardia meltada dunni Thomas, 1917

Subspecies: Millardia meltada meltada (Gray, 1837)

Millardia meltada singuri Mandal \& Ghosh, 1981

Distribution: Endemic to the region. Jammu \& Kashmir, Himachal Pradesh, Punjab, Haryana, Rajasthan, Gujarat, Uttar Pradesh, Maharshtra, Madhya Pradesh, Karnataka, Tamil Nadu, Andhra Pradesh, Chattisgarh, Jharkhand, Bihar, and West Bengal in India, Pakistan, Nepal, and Sri Lanka.

Comments: Possesses five plantar pads. Ellerman (1961) included this species under the genus Rattus Fischer, 1803 and recognized two subspecies, namely Rattus meltada meltada (Gray, 1837) and Rattus meltada pallidor (Ryley, 1914). Corbet and Hill (1992) listed three subspecies, namely, Millardia meltada pallidor Ryley, 1914, Millardia meltada dunni Thomas, 1917and Millardia meltada singuri Mandal \& Ghosh, 1981. Agrawal (2000) synonymized Millardia meltada pallidor Ryley, 1914 and Millardia meltada singuri Mandal \& Ghosh, 1981 with the nominate subspecies. However, Milardia meltada singuri Mandal \& Ghosh, 1981 has been retained here as a valid subspecies following Pradhan et al. (Comm.).

\section{Genus Mus Linnaeus, 1758 Mice}

This genus belongs to subfamily Murinae. One of the most complicated group of murids the world over as its classification remains unstable. Marshall's work (Marshall, 1977a,b, 1986) provides valuable clarifications regarding forms belonging to this genus in the Indo-Malayan region (Corbet \& Hill, 1992). Agrawal (2000) opines that though Marshall (1977b) overcame the anomalies in the taxonomy of platythrix-complex of species, but the problems in taxonomy of booduga - cervicolor still remains unresolved. Ellerman (1961) listed only two subgenera, Mus Linnaeus, 1758 and Coelomys Thomas, 1915. However, Asian forms have been classified under three subgenera, namely Mus Linnaeus, 1758, Pyromys Thomas, 1911, and Coelomys Thomas, 1915 (Corbet \& Hill, 1992). Eleven species are recognized from South Asia. Two species each are endemic to India and Sri Lanka.

\section{Mus booduga (Gray, 1837)}

1837. Leggada booduga Gray, Charlesworth's Mag. nat. Hist., 1:586.

Name: Common/Little Indian Field Mouse

Type locality: S. Mahratta (now probably somewhere in Karnataka), India

Synonyms: Leggada booduga Gray, 1837

Mus lepidus Elliot, 1839

Mus terricolor Blyth, 1851

Mus albidiventris Blyth, 1852

Mus beavanii Peters, 1866

Leggada dunni Wroughton, 1912

?Gatamyia weragami Deraniyagala, 1965

Subspecies: None

Distribution: Jammu \& Kashmir, Himachal Pradesh, Haryana, Uttaranchal, Uttar Pradesh, Madhya Pradesh, Maharashtra, Bihar, Jharkhand, Orissa, West Bengal, Karnataka, Tamil Nadu, Kerala, and parts of Rajasthan, Gujarat, Andhra Pradesh in India; Pakistan; Nepal; Sri Lanka and Bangladesh (Posamentier, 1989). Comments: This species belongs to subgenus Mus Linnaeus, 1758. Ellerman (1961) provisionally lists only two subspecies, namely Mus booduga booduga (GRay, 1837) and Mus booduga lepidoides (Fry, 1931). The former including the races 'lepida', 'terricolor', and 'dunni'. However, chromosomal evidence presented by Sharma et al. (1986) supports the specific status of both Mus booduga (Gray, 1837) and Mus terricolor Blyth, 1851, including Mus dunni (Wroughton, 1912). Still confusion persists regarding races and overlap of characters in the representative taxon belonging to the subgenus Mus. Hence to avoid confusions regarding forms akin to Mus booduga (Gray, 1837), Agrawal (2000) synonymized Mus dunni (Wroughton, 1912) and Mus terricolor Blyth, 1851 with Mus booduga (Gray, 1837), a trend earlier followed by Ellerman and Morrison-Scott (1951).

\section{Mus cervicolor Hodgson, 1845}

1845. Mus cervicolor Hodgson, Ann. Mag. nat. Hist., (1)15: 268.

Name: Fawn-coloured Mouse

Type locality: Nepal

Synonyms: Mus fulvidiventris Blyth, 1852 
Mus strophiatus Hodgson, 1845

? Mus cunicularius Blyth, 1855

Leggada nagarum imphalensis Roonwal, 1948

Subspecies: Mus cervicolor cervicolor Hodgson, 1845

Mus cervicolor fulvidiventris (Blyth, 1852)

Distribution: Jammu \& Kashmir (Chakraborty, 1983), Uttaranchal, West Bengal, Meghalaya, Manipur, Andaman \& Nicobar Islands, in India; Nepal, Pakistan (Taber et al., 1967); Sri Lanka and probably Bhutan.

Comments: This species belongs to subgenus Mus Linnaeus, 1758. Ellerman (1961) lists seven subspecies, namely Mus cervicolor phillipsi (Wroughton, 1912), Mus cervicolor fulvidiventris (Blyth, 1852), Mus cervicolor palnica (Thomas, 1923 ) - presently a synonym of Mus cookii Ryley, 1914, Mus cervicolor cervicolor Hodgson, 1845, Mus cervicolor nitidulus (Blyth, 1859), Mus cervicolor nagarum Thomas, 1921) presently a synonym of Mus cookii Ryley, 1914, and Mus cervicolor imphalensis (Roonwal, 1948). Corbet and Hill (1992) and Agrawal (2000) synonymized the last subspecies listed by Ellerman (1961) with the nominate Mus cervicolor cervicolor Hodgson, 1845.

\section{Mus cookii Ryley, 1914}

1914. Mus cookii Ryley, J. Bombay nat. Hist. Soc., 22: 664.

Name: Ryley's Spiny Mouse

Type locality: Gokteik, Shan States, N. Burma (now Myanmar)

Synonyms: Mus famulus cooki (sic) (Ryley, 1914)

Leggada nagarum Thomas, 1921

Mus cervicolor nagarum (Thomas, 1921)

Leggada palnica Thomas, 1924

Mus cervicolor palnica (Thomas, 1924)

Subspecies: Mus cookii cookii Ryley, 1914

Mus cookii nagarum (Thomas, 1921)

Distribution: Arunachal Pradesh, Assam, Meghalaya, Manipur, Nagaland, West Bengal, Maharashtra, Karnataka, Tamil Nadu and Kerala in India; Nepal, Bangladesh and Bhutan.

Comments: This species belongs to subgenus Mus Linnaeus, 1758. Ellerman and Morrison-Scott (1951), and Ellerman (1961) listed Leggada nagarum Thomas, 1921 and Leggada palnica Thomas, 1924 under Mus cervicolor Hodgson, 1845 as Mus cervicolor nagarum (Thomas, 1921) and Mus cervicolor planica (Thomas, 1924). They treated Mus cookii Ryley, 1914 as the subspecies of Mus famulus Bonhote, 1898, mainly because a number of characters overlap. Marshall (1977b) shifted them to Mus cookii Ryley, 1914. Agrawal (2000) validates only two subspecies, namely Mus cookii cookii Ryley, 1914 and Mus cookii nagarum (Thomas, 1921).

\section{Mus famulus Bonhote, 1898}

1898. Mus famulus Bonhote, J. Bombay nat. Hist. Soc., 12: 99.

Name: Bonhote's Mouse

Type locality: Coonoor, Nilgiri Hills, Tamil Nadu, India

Synonyms: None

Subspecies: None
Distribution: Endemic to India. Known only from two localities in the Nilgiri Hills, South India.

Comments: This species belongs to subgenus Coelomys Thomas, 1915. Ellerman (1961) listed three subspecies, namely Mus famulus famulus Bonhote, 1898, Mus famulus cooki (sic) (Ryley, 1914) and Mus famulus popaeus (Thomas, 1919). Mus famulus cooki (sic) (Ryley, 1914) is now considered as a separate species Mus cookii Ryley, 1914, and Mus famulus popaeus (Thomas, 1919) - earlier reported as Leggada nitidula popaea Thomas, 1919, has been proposed to be a subspecies of Mus cervicolor by Corbet and Hill (1992). Thus, presently only Mus famulus Bonhote, 1898 is a valid name from the region.

\section{Mus fernandoni (Phillips, 1932)}

1932. Leggadilla fernandoni Phillips, Spolia Zeylan., 16: 325.

Name: Ceylon Spiny Mouse

Type locality: Kubalgamuwa, Mulhalkelle Dist., Sri Lanka

Synonyms: Leggadilla fernandoni Phillips, 1932

Subspecies: None

Distribution: Endemic to Sri Lanka.

Comments: This species belongs to subgenus Pyromys Thomas, 1911. Phillips (1980) provides detailed information on this species.

\section{Mus mayori (Thomas, 1915)}

1915. Coelomys mayori Thomas, J. Bombay nat. Hist. Soc., 23: 3(415).

Name: Mayor's Mouse

Type locality: Pattipola, Central Mountains, Sri Lanka

Synonyms: Coelomys mayori Thomas, 1915

Coelomys bicolor Thomas, 1915

Subspecies: Mus mayori mayori (Thomas, 1915)

Mus mayori pococki Ellerman, 1947

Distribution: Endemic to Sri Lanka.

Comments: This species belongs to subgenus Coelomys Thomas, 1915. Ellerman (1961) listed two subspecies, namely Mus mayori mayori (Thomas, 1915) and Mus mayori pococki Ellerman, 1947.

\section{Mus musculus Linnaeus, 1758}

1758. Mus musculus Linnaeus, Syst. nat. 10 ${ }^{\text {th }}$ ed., 1: 62 .

Name: House Mouse

Type locality: Uppsala, Sweden

Synonyms: Mus nipalensis Hodgson, 1841 (nom. nud.)

Mus manei Gray, 1843

Mus bactrianus Blyth, 1846

Mus humourus Hodgson, 1845

Mus urbanus Hodgson, 1845

Mus dubius Hodgson, 1845

Mus darjilingensis Hodgson, 1849

Mus manei Kelaart, 1852

Mus gerbillinus Blyth, 1853

? Mus theobaldi Blyth, 1853

Mus tytleri Blyth, 1859

Mus musculus pygmaeus Biswas \& Khajuria, 1955 
Mus musculus khumbuensis Biswas \& Khajuria, 1968

Subspecies: Mus musculus praetextus (Brants, 1827)

Mus musculus homourus (Hodgson, 1845)

Mus musculus castaneus (Waterhouse, 1843)

Distribution: Throughout the range in South Asia including indoors and outdoors in India, Pakistan, Nepal, Bhutan, Bangladesh, and Sri Lanka.

Comments: This species belongs to subgenus Mus Linnaeus, 1758. Ellerman (1961) listed six subspecies, namely Mus musculus bactrianus (Blyth, 1846), Mus musculus humourus (Hodgson, 1845), Mus musculus castaneus (Waterhouse, 1843), Mus musculus urbanus (Hodgson, 1845), Mus musculus tytleri (Blyth, 1859), and Mus musculus pygmaeus Biswas \& Khajuria, 1955. Agrawal (2000) listed three subspecies, namely Mus musculus praetextus (Brants, 1827), Mus musculus humourus (Hodgson, 1845), and Mus musculus castaneus (Waterhouse, 1843). It is also possible that Mus musculus domesticus (Rutty, 1772) too may be spreading in the region through transportation. There is a potentially very confusing situation regarding Mus domesticus Schwarz \& Schwarz, 1943 which is generally regarded as the species occupying the western part of the Palearctic range. If this species occurs in Asia presumably it is introduced. However, the subspecies praetextus is attributed to this species (Mus domesticus Schwarz \& Schwarz, 1943 ), therefore its presence in Asia is confusing (Mike Jordan, Pers. Comm.)!

\section{Mus pahari Thomas, 1916}

1916. Mus pahari Thomas, J. Bombay nat. Hist. Soc., 24(3): 415. Name: Sikkim Mouse

Type locality: Batasia, Sikkim, India

Synonyms: Leggada jacksoniae Thomas, 1921

Mus pahari jacksoniae (Thomas, 1921)

Subspecies: Mus pahari pahari Thomas, 1916

Distribution: Sikkim, West Bengal, Arunachal Pradesh, Assam, Nagaland, Meghalaya and Mizoram in India; and Bhutan.

Comments: This species belongs to subgenus Coelomys Thomas, 1915. Ellerman (1961) listed two subspecies, namely Mus pahari pahari Thomas, 1916 and Mus pahari jacksoniae (Thomas, 1921). However, Agrawal (2000) synonymized the latter with the former and validated only the nominate race.

\section{Mus phillipsi Wroughton, 1912}

1912. Mus phillipsi Wroughton, J. Bombay nat. Hist. Soc., 21: 772.

Name: Wroughton's Small Spiny Mouse

Type locality: Asirgarh, Nimar, C. Province (now Madhya Pradesh), India

Synonyms: Leggadda (sic) surkha Wroughton \& Ryley, 1913 Leggada siva Thomas \& Ryley, 1913

Subspecies: None

Distribution: Endemic to the region. Rajasthan, Gujarat, Madhya Pradesh, Chattisgarh, Maharashtra, Andhra Pradesh, Karnataka, and Tamil Nadu in India; and Nepal.
Comments: This species belongs to subgenus Pyromys Thomas, 1911. Ellerman (1961) treated it as a subspecies of Mus cervicolor Hodgson, 1845. Marshall (1977b) restored it to specific level as earlier. Abe (1977) report its occurrence in Nepal, but list it as Mus cervicolor phillipsi (Wroughton, 1912).

\section{Mus platythrix Bennett, 1832}

1832. Mus platythrix Bennett, Proc. zool. Soc. Lond., 1832: 121. Name: Brown Spiny Mouse

Type locality: Dhukun, Peninsular India

Synonyms: Leggada bahadur Wroughton \& Ryley, 1913

Leggada grahami Ryley, 1913

Leggada hannyngtoni Ryley, 1913

Subspecies: Mus platythrix platythirx Bennett, 1832

Distribution: Endemic to India, and recorded from a number of localities in Maharashtra, Karnataka, Tamil Nadu, Andhra Pradesh, Madhya Pradesh, Rajasthan and West Bengal.

Comments: This species belongs to subgenus Pyromys Thomas, 1911. Ellerman (1961) listed six subspecies, namely Mus platythrix platythrix Bennett, 1832, Mus platythrix sadhu (Wroughton, 1911), Mus platythrix ramnadensis (Bentham, 1908), Mus platythrix bahadur (Wroughton \& Ryley, 1913), Mus platythrix gurkha (Thomas, 1914), and Mus platythrix shortridgei (Thomas, 1914). However, Marshall (1977b) has rearranged Mus platythrix complex under three species namely Mus platythrix Bennett, 1832, Mus saxicola Elliot, 1839 and Mus shortridgei (Thomas, 1914). The last species does not occur in South Asia.

\section{Mus saxicola Elliot, 1839}

1839. Mus saxicola Elliot, Madras J. Litt. Sci., 10: 215.

Name: Elliot's Spiny Mouse

Type locality: Madras, India

Synonyms: Mus spinulosus Blyth, 1854

Mus (Leggada) ramnadensis Bentham, 1908

Mus platythrix ramnadensis (Bentham, 1908)

Leggada platythrix sadhu Wroughton, 1911

Mus platythrix sadhu (Wroughton, 1911)

Leggada cinderella Wroughton, 1912

Leggadilla gurkha Thomas, 1914

Mus platythrix gurkha (Thomas, 1914)

Subspecies: Mus saxicola saxicola Elliot, 1839

Mus saxicola sadhu (Wroughton, 1911)

Mus saxicola gurkha (Thomas, 1914)

Distribution: Endemic to the region. Maharashtra, Karnataka, Tamil Nadu, Andhra Pradesh, Rajasthan, Gujarat, Madhya Pradesh, Himachal Pradesh, Uttaranchal, Jharkhand, and West Bengal in India; Pakistan; Nepal and Bangladesh.

Comments: This species belongs to subgenus Pyromys Thomas, 1911. Ellerman (1961) included the forms under Mus platythrix Bennett, 1832. See comments under Mus platythrix Bennett, 1832. Agrawal (2000) listed three subspecies, namely Mus saxicola saxicola Elliot, 1839, Mus saxicola sadhu (Wroughton, 1911), and Mus saxicola gurkha (Thomas, 1914). 


\section{Genus Nesokia Gray, 1842 \\ Palaearctic Bandicoot-rat}

This genus belongs to subfamily Murinae. One species recognized from South Asia.

66. Nesokia indica (Gray \& Hardwicke, 1832)

1832. Arvicola indica Gray (in Hardwicke, 1830-35), Illustr. Indian

Zool., 1, pl. xi.

Name: Short-tailed Bandicoot-rat

Type locality: (Uncertain), India

Synonyms: Arvicola indica Gray \& Hardwicke, 1832

Mus hardwickei Gray, 1837

Mus huttoni Blyth, 1846

Nesokia griffithi Horsfield, 1851

? Spalacomys indicus Peters, 1860

Nesokia beaba Wroughton, 1908

Subspecies: Nesokia indica indica (Gray \& Hardwicke, 1832) Distribution: Punjab, Haryana, Delhi, Uttaranchal, Uttar Pradesh, Rajasthan, Bihar and West Bengal in India; Nepal; Bangladesh (Posamentier, 1989); and Pakistan.

Comments: Ellerman (1961) included two subspecies, namely Nesokia indica indica (Gray \& Hardwicke, 1832), and Nesokia indica huttoni (Blyth, 1846). The latter form is distributed from Afghanistan and westward. Corbet and Hill (1992) opine that Nesokia indica chitralensis Schlitter and Setzer, 1976 could not be a discrete subspecies. Agrawal (2000) reported only the nominate subspecies from India. Musser and Carleton (1993) cite that substantial morphological variation is present among geographic samples and that careful systematic revision is required to determine whether this variation represents one or more species.

\section{Genus Niviventer Marshall, 1977 White-bellied Rats}

This genus belongs to subfamily Murinae. Ellerman (1961) included the forms representing this genus under the subgenus Maxomys Sody, 1936 of the genus Rattus Fischer 1803. Misonne (1969) included these under the Genus Maxomys Sody, 1936. Marshall (1977a) erected a new genus Niviventer to accommodate the species that differed from the true Maxomys Sody, 1936 species. Refer Marshall (1977a) for further details. Six species are recognized from South Asia.

\section{Niviventer brahma (Thomas, 1914)}

1914. Epimys brahma Thomas, J. Bombay nat. Hist. Soc., 23(2): 232.

Name: Thomas' Chestnut Rat

Type locality: Anzong Valley in Mishmi Hills, N. Assam (now Arunachal Pradesh), India

Synonyms: Epimys brahma Thomas, 1914

Subspecies: None Rattus fulvescens brahma (Thomas, 1914)

Distribution: Arunachal Pradesh in India.

Comments: Ellerman \& Morrison-Scott (1951), and Ellerman
(1961) treated this as a subspecies under Rattus fulvescens (Gray, 1847), but Musser (1970) restored it to the specific level under the genus Niviventer Marshall, 1977 and commented that the species is represented by only a few specimens.

68. Niviventer eha (Wroughton, 1916)

1916. Epimys eha Wroughton, J. Bombay nat. Hist. Soc., 24: 428.

Name: Little Himalayan Rat

Type locality: Lachen, Sikkim, India

Synonyms: Epimys eha Wroughton, 1916

Rattus eha (Wroughton, 1916)

Rattus eha eha (Wroughton, 1916)

Subspecies: Niviventer eha eha (Wroughton, 1916)

Distribution: Sikkim and West Bengal in India; and Nepal (Abe, 1971).

Comments: Ellerman (1961) included this species under genus

Rattus and listed two subspecies, namely Rattus eha eha (Wroughton, 1916) and Rattus eha ninus (Thomas, 1922). According to Agrawal (2000), the nominate species occurs in South Asia.

\section{Niviventer fulvescens (Gray, 1847)}

1847. Mus fulvescens Gray, Cat. Hodgson Coll. Br. Mus., 18.

Name: Chestnut Rat

Type locality: Nepal

Synonyms: Mus fulvescens Gray, 1847

Rattus fulvescens (Gray, 1847)

Mus caudatior Hodgson, 1849

Leggada jerdoni Blyth, 1863

Mus octomammis Gray, 1863

Subspecies: Niviventer fulvescens fulvescens (Gray, 1847)

Distribution: Himachal Pradesh, Uttaranchal, West Bengal, Sikkim, Assam, Meghalaya, Manipur and Arunachal Pradesh in India; Pakistan; Nepal; and also probably in Bhutan and Bangladesh.

Comments: Ellerman (1961) treated this under genus Rattus (Maxomys) Fischer, 1803, and listed two subspecies, namely Rattus fulvescens brahma (Thomas, 1914) and Rattus fulvescens fulvescens (Gray, 1847). Niethammer and Martens (1975) considered fulvescens as a synonym of niviventer. Agrawal (2000) mentioned that there are no valid subspecies under Niviventer fulvescens (Gray, 1847) from Indian region.

70. Niviventer langbianis (Robinson \& Kloss, 1922)

1922. Rattus langbianis Robinson \& Kloss, Ann. Mag. nat. Hist., (9)9: 96.

Name: Dark-tailed Rat

Type locality: Langbian Peak, S. Vietnam

Synonyms: Rattus langbianis Robinson \& Kloss, 1922

Rattus cremoriventer langbianis (Robinson \& Kloss, 1922)

Rattus indosinicus Osgood, 1932

Rattus cremoriventer indosinicus (Osgood, 1932)

Subspecies: None 
Distribution: Assam in India.

Comments: Ellerman (1961) treated this under Rattus cremoriventer (Miller, 1900). Musser (1981) treated Rattus langbianis Robinson \& Kloss, 1922 as a full species being distinct from Rattus cremoriventer (Miller, 1900) and assigned it to the genus Niviventer Marshall, 1977, and further, also synonymized Rattus indosinicus Osgood, 1932 with Niviventer langbianis (Robinson \& Kloss, 1922). Agrawal (2000) synonymized Rattus cremoriventer indosinicus (Osgood, 1932) with this species and opines that there are no subspecies for this taxon.

\section{Niviventer niviventer (Hodgson, 1836)}

1836. Mus (Rattus) niviventer Hodgson, J. Asiatic Soc. Bengal, $5: 234$.

Name: Himalayan White-bellied Rat

Type locality: Katmandu, Nepal

Synonyms: Mus (Rattus) niviventer Hodgson, 1836

Mus niveiventer Blanford, 1891

Epimys lepcha Wroughton, 1916

Rattus niviventer lepcha (Wroughton, 1916)

Subspecies: Niviventer niviventer lepcha (Wroughton, 1916)

Niviventer niviventer niviventer (Hodgson, 1836)

Distribution: Endemic to the region. Himachal Pradesh, Uttaranchal, West Bengal, Sikkim, Assam, Nagaland, Arunachal Pradesh, Meghalaya and Manipur in India; Nepal (Abe, 1977); Bhutan and probably in Pakistan.

Comments: Ellerman (1961) treated this under subgenus Maxomys Sody, 1936, and listed four subspecies, namely Rattus niviventer niviventer (Hodgson, 1836), Rattus niviventer lepcha (Wroughton, 1916), Rattus niviventer bukit (Bonhote, 1903), and Rattus niviventer mentosus (Thomas, 1916). Ghose (1964) proposed a subspecies Rattus niviventer monticola that Agrawal (2000) synonymised with Niviventer niviventer lepcha (Wroughton, 1916), one of the two subspecies occurring in South Asia.

\section{Niviventer tenaster (Thomas, 1916)}

1916. Epimys tenaster Thomas, Ann. Mag, nat. Hist., (8)17: 425. Name: Tenasserim Long-tailed Rat

Type locality: Mt. Mulaiyit, Tenasserim, Burma (now Myanmar) Synonyms: Epimys tenaster Thomas, 1916

Rattus cremoriventer tenaster (Thomas, 1916)

\section{Subspecies: None}

Distribution: Assam in India.

Comments: Ellerman (1961) treated this as a subspecies under Rattus cremoriventer (Miller, 1900), while Musser (1973) treated it as a form of Rattus niviventer (Hodgson, 1836) but later (Musser, 1981) considered it to be either a southern montane outlier of Niviventer confucianus (Milne-Edwards, 1872) or a distinct species. Agrawal (2000) does not list this species. Confusion about the status of this species still exists.

\section{Genus Rattus Fischer, 1803 \\ House Rats}

This genus belongs to subfamily Murinae. Thirteen species occur in the region. Among the four endemic species in India, two are insular species. Two species of this genus are endemic to Sri Lanka.

\section{Rattus burrus (Miller, 1902)}

1902. Mus burrus Miller, Proc. U. S. nation. Mus., 24: 768.

Name: Miller's Nicobar Rat

Type locality: Trinkut Island, Nicobar Isles, Andaman \& Nicobar Islands, India

Synonyms: Mus burrus Miller, 1902

Mus burrulus Miller, 1902

Mus burrescens Miller, 1902

Subspecies: None

Distribution: Endemic to India. Nicobar group of Islands, Andaman \& Nicobar Islands.

Comments: Ellerman (1961) treated this species along with Rattus burrulus (Miller, 1902) and Rattus burrescens (Miller, 1902) as conspecific. Corbet and Hill (1992) synonymized all the three species under Rattus tiomanicus (Miller, 1900) with doubtful status, and further commented that the "inclusion of the forms on the Andaman Islands is tentative, although the three forms described from there, burrus, burrulus and burrescens, are very similar to each other and probably conspecific". Agrawal (2000) remarks this being close to Rattus rattus (Linnaeus, 1758) and also mentions that the recent study by Musser and Heaney (1985) shows its affinity to Rattus tiomanicus (Miller, 1900).

\section{Rattus exulans (Peale, 1848)}

1848. Mus exulans Peale, Mammalia, in Repts. U. S. Explor. Surv., 8: 47.

Name: Polynesian Rat

Type locality: Tahiti Island, Society Islands (France)

Synonyms: Mus exulans Peale, 1848

Mus concolor Blyth, 1859

Subspecies: None

Distribution: Bangladesh.

Comments: Ellerman (1961) included this species under subgenus Rattus Fischer, 1803 and mentions about the Rattus exulans concolor (Blyth, 1859) from Myanmar region. Corbet and Hill (1992), and Musser and Carleton (1993) include Bangladesh in its distribution range in South Asia. This species does not occur in Indian limits (Agrawal, 2000).

\section{Rattus montanus Phillips, 1932}

1932. Rattus montanus Phillips, Ceylon Jour. Sci, Sec. B, 16: 323.

Name: Nillu Rat

Type locality: Ohiya, West Haputale, Sri Lanka

Synonyms: None

Subspecies: None

Distribution: Endemic to Sri Lanka. Known only from type 
locality.

Comments: Ellerman (1961) included this species under subgenus Rattus Fischer, 1803. Corbet and Hill (1992) remark that "it has been suggested that this name might be based upon a 'sample of extremely large Rattus rattus kelaarti males' (McKay, 1984) but the teeth are very distinctive and preclude that possibility, a conclusion supported by Musser (1986)". Phillips (1980) gives a detailed account of this species.

\section{Rattus nitidus (Hodgson, 1845)}

1845. Mus nitidus Hodgson, Ann. Mag. nat. Hist., (1)15: 267.

Name: Himalayan Rat

Type locality: Nepal

Synonyms: Mus nitidus Hodgson, 1845

Mus horeites Hodgson, 1845

Mus pyctoris Hodgson, 1845

Mus aequicaudalis Hodgson, 1849

Mus guhai Nath, 1952

Subspecies: Rattus nitidus nitidus (Hodgson, 1845)

Distribution: Uttaranchal, Sikkim, West Bengal, Arunachal Pradesh, Meghalaya, Tripura, Mizoram, and Manipur in India; Nepal; Bhutan; and Bangladesh.

Comments: Ellerman (1961) included this species under subgenus Rattus Fischer, 1803, and listed two subspecies, namely Rattus nitidus nitidus (Hodgson, 1845) and Rattus nitidus obsoletus Hinton, 1919. Corbet and Hill (1992) retained Rattus nitidus obsoletus Hinton, 1919, while Agrawal (2000) synonymized it with Rattus nitidus nitidus (Hodgson, 1845) based on overlap of characters. Marshall (1977a) synonymised Mus guhai Nath (1952) with this species as the description of Mus guhai Nath (1952) was based upon a litter of Rattus nitidus (Hodgson, 1845).

\section{Rattus norvegicus (Berkenhout, 1769)}

1769. Mus norvegicus Berkenhout, Outlines nat. Hist. Gt. Britain and Ireland, 1: 5.

Name: Norway / Brown Rat

Type locality: Great Britain

Synonyms: Mus norvegicus Berkenhout, 1769

Mus decumanoides Hodgson, 1814 (nom. nud.)

Subspecies: Rattus norvegicus norvegicus (Berkenhout, 1769) Distribution: India, Pakistan and Sri Lanka

Comments: Ellerman (1961) included this species under subgenus Rattus Fischer, 1803. Ellerman (1961), Spillet (1968), Phillips (1980), Pradhan (1975), Corbet and Hill (1992), and Agrawal (2000) opine that this species has been introduced by human agencies through transportation, and it is restricted to large cities only. The species is ground dwelling in habit.

\section{Rattus palmarum (Zelebor, 1869)}

1869. Mus palmarum Zelebor, Reise der Oesterr., Fregatte Novara, Zool. Th. I, Wirbelth., 1, Saugeth., 26.

Name: Zelebor's Nicobar Rat / Palm Rat

Type locality: Car Nicobar (probably), Andaman \& Nicobar Islands, India
Synonyms: Mus palmarum Zelebor, 1869

Subspecies: None

Distribution: Endemic to India. Nicobar Islands, Andaman and Nicobar Islands.

Comments: Corbet and Hill (1992), Musser and Carleton (1993) and Agrawal (2000) following Musser and Heaney (1985), and Musser and Newcomb (1983) remark that it is most closely related to Rattus tiomanicus (Miller, 1900). It is known from only very few specimens in the original series.

\section{Rattus ranjiniae Agrawal \& Ghosh, 1969}

1969. Rattus ranjiniae Agrawal \& Ghosh, Proc. zool. Soc. Calcutta, 22: 41-45.

Name: Ranjini's Field Rat

Type locality: Trivandrum, Kerala, India

Synonyms: None

Subspecies: None

Distribution: Endemic to India. Reported from Thrissur, Alleppey, and Thiruvananthapuram districts of Kerala.

Comments: Corbet and Hill (1992) opined that its inclusion as a member of subgenus Rattus Fischer, 1803 is open to question. This distinctive species is known from very few specimens.

\section{Rattus rattus (Linnaeus, 1758)}

1758. Mus rattus Linnaeus, Syst. Nat., $10^{\text {th }}$ ed., 1: 61.

Name: Common House Rat

Type locality: Uppsala, Sweden

Synonyms: Mus rattus Linnaeus, 1758

Rattus rattus alexandrinus (Geoffroy, 1803)

Mus indicus Desmarest, 1832

Mus rufescens Gray, 1837

? Mus asiaticus Gray, 1837

Mus flavescens Elliot, 1839

Mus brunneus Hodgson, 1845

Mus kandianus Kelaart, 1850

Mus ceylonus Kelaart, 1850

Rattus rattus ceylonus (Kelaart, 1850)

Mus tetragonurus Kelaart, 1850

Mus arboreus Horsfield, 1851

Mus nemoralis Blyth, 1851

? Mus crassipes Blyth, 1859

Mus (Leggada) andamensis Blyth, 1860

Rattus rattus andamensis (Blyth, 1860)

Mus infralineatus Blyth, 1863 (nom. nud.)

Mus kandiyanus Kelaart, 1867 (emend.)

? Mus flebilis Miller, 1902

Rattus ? rattus flebilis (Miller, 1902)

? Mus pulliventer Miller, 1902

Mus atratus Miller, 1902

Mus atridorsum Miller, 1903

Epimys kelaarti Wroughton, 1915

Rattus rattus girensis Hinton, 1918

Subspecies: Rattus rattus rattus (Linnaeus, 1758)

Rattus rattus rufescens (Gray, 1837) 
Rattus rattus brunneus (Hodgson, 1845)

Rattus rattus kandianus (Kelaart, 1850)

Rattus rattus arboreus (Horsfield, 1851)

Rattus rattus kelaarti (Wroughton, 1915)

Rattus rattus tistae Hinton, 1918

Rattus rattus bhotia (Hinton, 1918)

Rattus rattus narbadae Hinton, 1918

Rattus rattus satarae Hinton, 1918

Rattus rattus wroughtoni Hinton, 1919

Rattus rattus gangutrianus Hinton, 1919

Rattus rattus khyensis Hinton, 1919

Rattus rattus tikos Hinton, 1919

Rattus rattus bullocki Roonwal, 1948

Distribution: India, Pakistan, Nepal, Bhutan, Bangladesh, and

Sri Lanka.

Comments: Ellerman (1961) included 22 subspecies under this species. Out of these Rattus rattus alexandrinus (Geoffroy, 1803); Rattus rattus ceylonus (Kelaart, 1850); and Rattus rattus andamensis (Blyth, 1860) have been synonymized under Rattus rattus (Linnaeus, 1758) by Corbet and Hill (1992). In all 15 above mentioned subspecies have been retained by Corbet and Hill (1992) on the basis of extremely generalised trend of variations and superficial sampling of the main collection. Further, Corbet and Hill (1992) doubtfully synonymized Rattus rattus macmillani Hinton, 1914 with Rattus remotus (Robinson \& Kloss, 1914). Rattus rattus rattus (Linnaeus, 1758) [Corbet and Hill (1992) do not include this name], an European Black Rat, is a valid subspecies and has been introduced in the port cities like Mumbai, Kolkata etc. through transportation by human agencies (Pradhan and Hemkar, 1986); Rattus rattus bullocki Roonwal, 1948 has been retained as a subspecies by Corbet and Hill (1992), while Rattus rattus khumbuensis Biswas \& Khajuria, 1955 has been treated as Rattus turkestanicus khumbuensis (Biswas \& Khajuria, 1955) by Agrawal, (2000). Phillips (1980) listed five subspecies of Rattus rattus (Linnaeus, 1758) from Sri Lanka, of which Rattus rattus rattus Linnaeus, 1758), Rattus rattus rufescens (Gray, 1837), and Rattus rattus kelaarti (Wroughton, 1915) are currently considered as valid subspecies, while Rattus rattus alexandrinus (Geofroy, 1803) has been synonymized by Corbet and Hill (1992). Furthermore, Corbet and Hill (1992), include a few other subspecies names from the region, like, Rattus rattus girensis Hinton, 1918 [we synonymized this with Rattus rattus (Linnaeus, 1758) following Ellerman \& Morrison-Scott (1951)]; and ?Rattus rattus holchu Chaturvedi, 1966. The status of the latter subspecies needs confirmation. Corbet and Hill (1992) has been followed in this particular species while listing the above mentioned subspecies of Rattus rattus (Linnaeus, 1758), since Agrawal, (2000) has not dealt with Rattus rattus (Linnaeus, 1758) at subspecies level. But, Musser and Carleton (1993), and Mike Jordan (pers. comm.) opine that the subspecies wroughtoni, tistae, bhotia, bullocki, khyensis and tickos, which all belong to the $2 \mathrm{n}=42$ chromosome group of Rattus rattus (Linnaeus, 1758) are subspecies of Rattus tanezumi (Temminck, 1844) [also see comments under Rattus tanezumi (Temminck, 1844)]. However, Raman and Sharma (1977) have reported chromosome number $2 n=38$ or 42 in Rattus rattus (Linnaeus, 1758) too (Agrawal, 2000). Remarking on the subspecies variation under Rattus rattus (Linnaeus, 1758), Agrawal (2000) opined that "it is not possible, at present, to correctly classify all the subspecies of Rattus rattus, due to lack of sufficient fresh specimen for study, of all the described subspecies from India and adjoining countries". Therefore, it is clear that to understand subspecies variation of Rattus rattus (Linnaeus, 1758) needs thorough revisionary studies based on karyological, biochem-taxonomical, morphological, osteological, genetic relationship, geographical distribution, is needed.

\section{Rattus sikkimensis Hinton, 1919}

1919. Rattus rattus sikkimensis Hinton, J. Bombay nat. Hist. Soc., 26: 394.

Name: Sikkim Rat

Type locality: Pashok, Sikkim, India

Synonyms: Mus brunneusculus Hodgson, 1845

Rattus rattus brunneusculus (Hodgson, 1845)

Rattus rattus sikkimensis Hinton, 1919

Subspecies: None

Distribution: Sikkim, West Bengal, Meghalaya, Nagaland, Arunachal Pradesh and Manipur in India; and Nepal (Musser and Heaney, 1985).

Comments: Ellerman (1961) synonymized Rattus rattus sikkimensis Hinton, 1919 with Rattus rattus brunneusculus (Hodgson, 1845). Musser and Heaney (1985) suggested that Rattus remotus (Robinson \& Kloss, 1914) is 'really an insular population of Rattus sikkimensis'. However, Corbet and Hill (1992) synonymized Rattus rattus sikkimensis Hinton, 1919 with Rattus remotus (Robinson \& Kloss, 1914) based on the argument that latter name is prior to the former. However, Musser and Carleton (1993), and Agrawal (2000) treat it as a distinct species.

\section{Rattus stoicus (Miller, 1902)}

1902. Mus stoicus Miller, Proc. U. S. nation. Mus., 24: 759.

Name: Andaman Rat/Miller's Long-footed Rat

Type locality: Henry Lawrence Island, Andaman Isles, Andaman \& Nicobar Islands, India

Synonyms: Mus stoicus Miller, 1902

Mus taciturnus Miller, 1902

Mus rogersi Thomas, 1907

Rattus rogersi (Thomas, 1907)

Subspecies: None

Distribution: Endemic to India. Andaman Islands, Andaman and Nicobar Islands.

Comments: Ellerman (1961) opined that it "possibly represents Rattus palmarum; possibly a member of sabanus group, or perhaps a representative of mulleri group". Musser and Heaney (1985) redescribed this species. Corbet and Hill (1992), and Agrawal (2000) consider it as a distinct species. 


\section{Rattus tanezumi (Temminck, 1844)}

1844. Mus tanezumi Temminck, In Seibold, Temminck, \& Schlegel, Fauna Japonica, Arnz et Socii, Lugduni Batavorum, 51, pl. 15, figs. 5-7.

Name: Tanezumi Rat

Type locality: Probably near Nagasaki on Kyushu Island, Japan Synonyms: Mus tanezumi Temminck, 1844

Subspecies: None

Distribution: According to Musser and Carleton(1993), Pakistan; North India; Nepal; probably Bhutan; Andaman Isles., some of the Nicobar Isls. and also S.W. peninsular India.

Comments: Musser and Carleton (1993) opine that this species varies from Rattus rattus (Linnaeus, 1758) $(2 \mathrm{~N}=38 / 40)$ by chromosomal $(2 \mathrm{~N}=42)$, morphological and biochemical traits. The indigenous range of this species is generally north Pakistan to northeast India in South Asia (Musser \& Carleton, 1993). Six of the subspecies attributed to Rattus rattus (Linnaeus, 1758) (sensu stricto) would be attributable to this species [see comments under Rattus rattus (Linnaeus, 1758)] including the one southern subspecies 'wroughtoni' $(2 \mathrm{~N}=42)$ having this chromosomal character. Thus, they may all possibly belong to Rattus tanezumi (Temminck, 1844), rather than to Rattus rattus (Linnaeus, 1758) as accepted. If this is accepted, then Rattus rattus wroughtoni Hinton, 1919 will become Rattus tanezumi wroughtoni (Hinton, 1919) so as the rest of the subspecies with $2 \mathrm{~N}=42$ (Mike Jordan, pers. comm.). However, Raman and Sharma (1977) have reported chromosome number $2 n=38$ or 42 in Rattus rattus (Linnaeus, 1758) too (Agrawal, 2000). Moreover, Corbet and Hill (1992), and Agrawal (2000) do not mention anything about this species. Therefore, a status quo has been retained in this particular case.

\section{Rattus turkestanicus (Satunin, 1903)}

1903. Mus turkestanicus Satunin, Ann. Mus. Zool. Acad. Imp. Sci., St. Petersburg, 7: 588.

Name: Turkestan Rat

Type locality: Arslanbob, Oshkaya, Kirghizia

Synonyms: Mus turkestanicus Satunin, 1903

Mus rattoides Hodgson, 1845

? Mus pyctoris Hodgson, 1845

Epimys rattus shigarus Miller, 1913

Rattus rattus shigarus (Miller, 1913)

Subspecies: Rattus turkestanicus turkestanicus (Satunin, 1903)

Rattus turkestanicus khumbuensis Biswas \& Khajuria, 1955

Rattus turkestanicus gilgitianus Akhtar, 1959

Distribution: Jammu \& Kashmir, Himachal Pradesh, Uttaranchal, West Bengal, Sikkim in India (Agrawal, 2000); Nepal (Abe, 1971); Pakistan; Bhutan and Bangladesh

Comments: Ellerman (1961) included this species under Rattus rattoides (Hodgson, 1845) and listed Rattus rattoides rattoides (Hodgson, 1845) and Rattus rattoides turkestanicus (Satunin, 1903). The name Rattus rattoides (Hodgson, 1845) [earlier Mus rattoides Hodgson, 1845] was found to be preoccupied by Mus rattoides Pictet \& Pictet, 1844 from Brazil, hence Schlitter and Thonglongya (1971) replaced it with the next available name Mus turkestanicus Satunin 1903 [later Rattus turkestanicus (Satunin, 1903)]. Corbet and Hill (1992) synonymized Rattus rattus khumbuensis Biswas \& Khajuria 1955 with Rattus turkestanicus (Satunin, 1903). Agrawal (2000) dealt in detail about the existing overlaps of published information regarding forms of this species reported from Nepal, and opined that to accommodate Nepal specimens earlier named Rattus rattoides rattoides (Hodgson, 1845) be replaced by the name Rattus turkestanicus khumbuensis Biswas \& Khajuria, 1955. Roberts (1997) has made a reference of a distinct subspecies, Rattus turkestanicus gilgitianus Akhtar, 1955 occurring in Gilgit (Pakistan). This species may include two or more taxa and requires revision. Musser and Carleton (1993) point out that the oldest name for the complex is pyctoris (Hodgson, 1845); incorrectly listed as a synonym of Rattus nitidus (Hodgson, 1845) by Ellerman, 1961 and would replace turkestanicus if all samples represent a single species, or would identify the Nepal and Sikkim populations if not conspecific.

\section{Rattus vicerex (Bonhote, 1903)}

1903. Mus vicerex Bonhote, Ann. Mag. nat. Hist., 11: 473.

Name: Short-tailed Turkestan Rat

Type locality: Shimla, North India

Synonyms: Mus vicerex Bonhote, 1903

Subspecies: None

Distribution: Endemic to the region. Jammu \& Kashmir, Himachal Pradesh in India; and Pakistan.

Comments: Ellerman (1961) synonymized Mus vicerex Bonhote, 1903 with Rattus rattoides turkestanicus (Satunin, 1903), a trend also followed by Corbet and Hill (1992), and Musser and Carleton (1993). However, Chakraborty (1983) restored Rattus vicerex (Bonhote, 1903) on the basis of tail characters, and later Agrawal (2000) maintained the same stand and treated it as full species. See Agrawal (2000) for further details.

\section{Genus Srilankamys Musser, 1981}

This genus belongs to subfamily Murinae. Musser (1981) erected this genus Srilankamys to accommodate Rattus ohiensis Phillips, 1929 - an unique Sri Lankan endemic Rat that was in past been assigned to different subgenera by different authors.

\section{Srilankamys ohiensis (Phillips, 1929)}

1929. Rattus ohiensis Phillips, Ceylon. J. Sci., Sec. B, 15: 167.

Name: Ohiya Rat

Type locality: West Haputale, Ohiya, Sri Lanka

Synonyms: Rattus ohiensis Phillips, 1929

Subspecies: None

Distribution: Endemic to Sri Lanka.

Comments: Ellerman (1961) listed it as Rattus ohiensis Phillips, 1929. Corbet and Hill (1992) remark that this species was included 
with considerable reservations, in Rattus (Apomys) by Ellerman (1949), in Rattus (Lenothrix) by Ellerman (1961), and in Rattus (Leopoldamys) by Misonne (1969). Subsequently, Musser (1981) erected the genus Srilankamys to accommodate this very distinctive species.

\section{Genus Vandeleuria Gray, 1842 Long-tailed Tree Mice}

This genus belongs to subfamily Murinae. Ellerman (1961) listed one species, namely Vandeleuria oleracea (Bennett, 1832) including seven subspecies. This genus differs from others in not possessing claws on the fifth finger and toe (Agarwal \& Chakraborty, 1980). Two species are recognized from South Asia, of which one is endemic to Sri Lanka.

87. Vandeleuria nolthenii (Phillips, 1929)

1929. Vandeleuria nilagirica nolthenii Phillips, Ceylon J. Sci., Sec. B, 15: 165.

Name: Ceylon Highland Tree Mouse

Type locality: West Haputale, Ohiya, Sri Lanka

Synonyms: Vandeleuria nilagirica nolthenii Phillips, 1929

Vandeleuria oleracea nolthenii (Phillips, 1929)

Subspecies: None

Distribution: Endemic to Sri Lanka.

Comments: Ellerman (1961) and Agrawal and Chakraborty (1980)

included this form under Vandeleuria oleracea (Bennett, 1832).

Corbet and Hill (1992) quoting Musser (1979) treated it as a species by itself separate from Vandeluria oleracea (Bennett, 1832), a trend also accepted by Musser and Carleton (1993) by virtue of its distinct montane distribution, pelage colouration, external and cranial traits.

88. Vandeleuria oleracea (Bennett, 1832)

1832. Mus oleraceus Bennett, Proc. Zool. Soc. London, 1832: 121.

Name: Indian Long-tailed Tree Mouse

Type locality: Deccan, India

Synonyms: Mus oleraceus Bennett, 1832

Mus dumeticola Hodgson, 1845

Mus povensis Hodgson, 1845

Mus nilagiricus Jerdon, 1867

Vandeleuria wroughtoni Ryley, 1914

Vandeleuria oleracea spadicea Ryley, 1914

Vandeleuria rubida Thomas, 1914

Vandeleuria oleracea rubida Thomas, 1914

Vandeleuria oleracea modesta Thomas, 1914

Vandeleuria oleracea marica Thomas, 1914

Subspecies: Vandeleuria oleracea oleracea (Bennett, 1832)

Vandeleuria oleracea dumeticola (Hodgson, 1845)

Distribution: Punjab, Haryana, Rajasthan, Uttaranchal, Himachal Pradesh, Jharkhand, West Bengal, Orissa, Assam, Meghalaya, Nagaland, Mizoram, Manipur, Arunachal Pradesh, Gujarat, Madhya Pradesh, Chattisgarh, Andhra Pradesh, Maharashtra,
Karnataka, and Tamil Nadu in India; Nepal, Bhutan, Bangladesh, and Sri Lanka.

Comments: As mentioned above Ellerman (1961) listed seven subspecies. Corbet and Hill (1992) list three probable subspecies, namely Vandeleuria oleracea spadicea Ryley, 1914, Vandeleuria oleracea modesta Thomas, 1914 and Vandeleuria oleracea marica Thomas, 1914 from this region. The last subspecies was synonymized earlier by Ellerman (1961) to Vandeluria oleracea dumeticola (Hodgson, 1845). Recently, Agrawal (2000), while synonymizing most of the earlier mentioned subspecies, retained only two valid subspecies, namely Vandeluria oleracea oleracea (Bennett, 1832) and Vandeleuria oleracea dumeticola (Hodgson, 1845) from the region.

\section{Subfamily: Platacanthomyinae Genus Platacanthomys Blyth, 1859 Spiny Dormouse}

This genus belongs to the subfamily Platacanthomyinae. Ellerman (1961) and Agrawal (2000) opine that this genus is monotypic and endemic to India.

\section{Platacanthomys lasiurus Blyth, 1859}

1859. Platacanthomys lasiurus Blyth, J. Asiat. Soc. Beng., 28: 289.

Name: Malabar Spiny Dormouse

Type locality: Alipi (now Allepey), Malabar (now Kerala), southern India

Synonyms: None

Subspecies: None

Distribution: Endemic to India. Kerala, Karnataka and Tamil Nadu in India.

Comments: Ellerman (1961), Corbet and Hill (1992), and Agrawal (2000) have not offered any comment on the taxonomic status of this species.

\section{Subfamily: Rhizomyinae Genus Cannomys Blyth, 1859 Bamboo Rat}

This genus belongs to the subfamily Rhizomyinae that includes two genera in the region. Ellerman (1961), Corbet and Hill (1992), and Agrawal (2000) opine that this genus is monotypic.

\section{Cannomys badius (Hodgson, 1841)}

1841. Rhizomys badius Hodgson, Calcutta J. nat. Hist., 2: 60.

Name: Bay Bamboo Rat

Type locality: Nepal.

Synonyms: Rhizomys badius Hodgson, 1841

Subspecies: None

Distribution: West Bengal, Assam, Meghalaya, Manipur, Nagaland, Mizoram in India; Nepal and probably also in Bhutan and Bangladesh

Comments: Ellerman (1961) listed three subspecies, namely Cannomys badius badius (Hodgson, 1841), Cannomys badius 
castaneus (Blyth, 1843), and Cannomys badius pater (Thomas, 1911). Corbet and Hill (1992) also list Cannomys badius plumbescens (Thomas, 1915), a subspecies that was earlier synonymized to Cannomys badius castaneus (Blyth, 1843) by Ellerman (1961). Agrawal (2000) synonymized all the three subspecies, namely Cannomys badius castaneus (Blyth, 1843), Cannomys badius plumbescens (Thomas, 1915) and Cannomys badius pater (Thomas, 1911) with the nominate subspecies Cannomys badius badius (Hodgson, 1841).

\section{Genus Rhizomys Blyth, 1859 \\ Bamboo Rat}

This genus belongs to the subfamily Rhizomyinae and is represented by a one species in the region (Ellerman, 1961; Corbet \& Hill, 1992; Agrawal, 2000). Ellerman (1961) listed it under the subgenus Rhizomys Gray, 1831.

\section{Rhizomys pruinosus Blyth, 1851}

1851. Rhizomys pruinosus Blyth, J. Asiat. Soc. Bengal, 20: 519. Name: Hoary Bamboo Rat

Type locality: Cherrapunji, Khasi Hills, Meghalaya, India

Synonyms: None for the region

Subspecies: None

Distribution: Meghalaya, Nagaland, and Manipur in India.

Comments: Ellerman (1961), Corbet and Hill (1992), and Agrawal (2000) do not offer any comment on the taxonomic status of this species.

\section{Acknowledgements}

We thank Dr. J.R.B. Alfred, Director, Zoological Survey of India, Kolkatta and Officer-in-Charge, Zoological Survey of India, Western Regional Station, Pune for facilities. We thank Dr. V. C. Agrawal, Emeritus Scientist, Zoological Survey of India for sharing his views on murids of India with CS. Ms. Sally Walker and Mr. Sanjay Molur, Zoo Outreach Organization, Coimbatore helped us in many ways. Dr. Mike J.R. Jordan, Sparsholt College, England (presently Chester Zoo, England) helped us with initial list and provided valuable comments on the first draft of the paper. MSP acknowledges the assistance rendered by Shri S. S. Talmale, ZSI, WRS, Pune in preparation of the list. CS thanks Dr. V. Nagulu and the Head, Department of Zoology, Osmania University, Hyderabad for encouragement; Dr. Bhargavi Srinivasulu of Department of Zoology, Osmania University, and Ms. A.R. Binu Priya and Ms. K. Padma Priya of Zoo Outreach Organization, Coimbatore for their help in literature survey and preparation of the final checklist. CS acknowledges the Research Grant from CSIR, New Delhi.

\section{References}

Abe, H. (1971). Small mammals of central Nepal. Journal of the Faculty of Agriculture, Hokkaido University, Sapporo, Japan 56: 367-423.

Abe, H. (1977). Variation and taxonomy of some small mammals from central Nepal. Journal Mammalian Society of Japan 7(2): 63-73. Agrawal, V.C. (1967a). Taxonomic study of the skulls of Oriental rodents in relation to ecology. Records of the Indian Museum 60: 125 326.

Agrawal, V.C. (1967b). New mammal records from Rajasthan. Labdev. Journal of Science and Technology 5: 342-344.

Agrawal, V.C. (1970). Taxonomic status of Millardia Thomas (Rodentia: Muridae). Mammalia 34: 496-504.

Agrawal, V.C. (1973). Notes on collection of mammals from Goa. Records of the Zoological Survey of India 67: 261-280.

Agrawal, V.C. (2000). Taxonomic studies on Indian Muridae and Hystricidae (Mammalia: Rodentia). Records of the Zoological Survey of India, Miscellaneous Publication, Occasional Paper No. 180, 1$177 \mathrm{pp}$.

Agrawal, V.C. and S. Chakraborty (1971). Notes on a collection of small mammals from Nepal, with the description of a new mousehare (Lagomorpha: Ochotonidae). Proceedings of the Zoological Society of Calcutta 24: 41-46.

Agrawal, V.C. and S. Chakraborty (1976). Revision of the subspecies of the Lesser Bandicoot Rat, Bandicota bengalensis (Gray) (Rodentia: Muridae). Records of the Zoological Survey of India 69: 267-274.

Agrawal, V.C. and S. Chakraborty (1980). Intraspecific geographical variations in the Long-tailed Tree Mouse, Vandeleuria oleracea (Bennett). Bulletin of the Zoological Survey of India 3: 77-85.

Agrawal, V.C. and S. Chakraborty (1981). Notes on the intraspecific geographical variation in the Indian Antelope Rat, Tatera indica (Hardwicke) (Mammalia: Rodentia). Records of the Zoological Survey of India 79: 83-92.

Agrawal, V.C. and S. Chakraborty (1982). Intraspecific geographical variations in the Indian Bush Rat, Golunda ellioti J.E. Gray. Records of the Zoological Survey of India 79: 521-530.

Bates, P.J.J. (1988). Systematics and zoogeography of Tatera (Rodentia: Gerbillinae) of north-east Africa and Asia. Bonner Zoologishe Beitrage 39: 265-303.

Bates, P.J.J. (1994). The distribution of Acomys (Rodentia: Muridae) in Africa and Asia. Israel Journal of Zoology 40: 199-214.

Biswas, B. and H. Khajuria (1955). Zoological results of the 'Daily Mail' Himalayan Expedition 1954. Four new mammals from Khumbu, Eastern Nepal. Proceedings of the Zoological Society of Calcutta 8: 26-29.

Biswas, B. and H. Khajuria (1957). Zoological results of the 'Daily Mail' Himalayan Expedition 1954. Notes on some mammals of Khumbu, Eastern Nepal. Proceedings of the Zoological Society of Calcutta, Mukherjee Memorial Volume. 229-253pp.

Biswas, B. and K.K. Tiwari (1969). Taxonomy and distribution of Indian Rodents. Proceedings of the Indian Rodent Symposium, Calcutta 1969, 9-45pp.

Blanford, W.T. (1888). The Fauna of British India. Mammalia, Part 1, Taylor and Francis, London, 250pp.

Blanford, W.T. (1891). The Fauna of British India. Mammalia, Part 2. Taylor and Francis, London, 617+xx pp.

Blyth, E. (1863). A memoir on the rats and mice of India. Journal of the Asiatic Society of Bengal 32: 327-353.

Carleton, M.D. and G.G. Musser (1984). Muroid rodents, pp. 289379. In: Anderson, S. and J.K. Jones, Jr. (editors.) Orders and Families of Recent Mammals of the World. John Wiley and Sons, New York, $686 \mathrm{pp}$.

Carleton, M.D. and G.G. Musser (1989). Systematic studies of oryzomyine rodents (Muridae, Sigmodontinae): a synopsis of Microryzomys. Bulletin of the American Museum of Natural History 191: 1-83. 
Chakraborty, R. and S. Chakraborty (1991). Taxonomic review of the genus Bandicota Gray and its species with a note on the intraspecific geographical variation in the Large Bandicoot Rat (Bandicota indica Bechstein). Records of the Zoological Survey of India 88: 87-99.

Chakraborty, S. (1975). On collection of mammals from Bhutan. Records of the Zoological Survey of India 68: 1-20.

Chakraborty, S. (1983). Contribution to the knowledge of the mammalian fauna of Jammu and Kashmir, India. Records of the Zoological Survey of India, Miscellaneous Publication, Occasional Paper No. 38: 1-129.

Corbet, G.B. (1978). The Mammals of the Palaearctic Region: A Taxonomic Review. British Museum (Natural History), London, 314 pp.

Corbet, G.B. and J.E. Hill (1980). A World List of Mammalian Species. British Museum (Natural History), London, 226pp.

Corbet, G.B. and J.E. Hill (1986). A World List of Mammalian Species. $2^{\text {nd }}$ edition, British Museum (Natural History), London, $254 \mathrm{pp}$.

Corbet, G.B. and J.E. Hill (1991). A World List of Mammalian Species. $3^{\text {rd }}$ edition, British Museum (Natural History) Publications, London, 243pp.

Corbet, G. B. and J.E. Hill (1992). Mammals of the Indomalayan Region: A systematic Review. Oxford University Press, Oxford, 488pp. Denys, C., J.C. Gautun, M. Tranier and V. Volobouev (1994). Evolution of the genus Acomys (Rodentia: Muridae) from dental and chromosomal patterns. Israel Journal of Zoology 40: 215-246.

Ellerman, J.R. (1941). The Families and Genera of Living Rodents. Vol. II. Family Muridae. British Museum (Natural History), London, 690pp.

Ellerman, J.R. (1947a). A key to the Rodentia inhabiting India, Ceylon and Burma based on the collections in the British Museum. Part 1. Journal of Mammalogy 28: 249-278.

Ellerman, J.R. (1947b). A key to the Rodentia inhabiting India, Ceylon and Burma based on the collections in the British Museum. Part 2. Journal of Mammalogy 28: 357-387.

Ellerman, J.R. (1949). The Families and Genera of Living Rodents. Vol. III. Family Muridae. Appendix II [Notes on the rodents from Madagascar in the British Museum, and on a collection from the island obtained by Mr. C.S. Webb]. British Museum (Natural History), London, 210pp.

Ellerman, J.R. (1961). The Fauna of India Including Pakistan, Burma and Ceylon: Mammalia, Rodentia. Volume 3 (in 2 parts). Second ed. Manager of Publications, Zoological Survey of India, Calcutta, Vol. 1: 1-482 \& Vol. 2: 483-884.

Ellerman, J. R. and T. C. S. Morrison-Scott (1951). Checklist of Palaearctic and Indian Mammals 1758 to 1946. Trustees of the British Museum (Natural History), London, 810pp.

Ellerman, J. R. and T. C. S. Morrison-Scott (1953). Checklist of Palaearctic and Indian mammals - amendments. Journal of Mammalogy 34: 516-518.

Feng Zuo-jian, Cai Gui-quan and Zheng Chang-lin (1986). Hsitsang pu ju lei [Mammals of Tibet]. Sci. Press, Pei-ching, 423pp.

Fry, T. B. (1931). Proposed classification of the smaller Indian Field (or jungle) mice. Journal of the Bombay Natural History Society 34(4): 916-921.

Gemmeke, H. and J. Niethammer (1982). Zur Charakterisierung der Waldmàuse (Apodemus) Nepals. Zeitschrift für Säugetierkunde, 47: 33-38.
Ghose, R.K. (1964). A new rat of the genus Rattus Fischer, 1803 (Mammalia: Rodentia) from Darjeeling district, West Bengal. Proceedings of the Zoological Society of Calcutta 17: 193-197.

Harrison, D.L. (1972). The Mammals of Arabia. Ernest Benn Limited, London, Vol. 3: 383-670.

Harrison, D.L. and P.J.J. Bates (1991). The Mammals of Arabia, Second ed. Harrison Zoological Museum, Sevenoaks, United Kingdom, $354 \mathrm{pp}$.

Hinton, M.A.C. (1926). Monograph of the Voles and Lemmings (Microtinae) Living and Extinct. Volume 1. British Museum (Natural History), London, $488 \mathrm{pp}$.

Ingles, J. M., P.N. Newton, M.R.W. Rands and C.G.R. Bowden (1980). The first record of a rare murine rodent Diomys and further records of three shrew species from Nepal. Bulletin of the British Museum (Natural History), Zoology Series 39: 205-211.

Jerdon, T.C. (1874). The Mammals of India: Natural History. John Wheldon, London, $335 \mathrm{pp}$.

Koffler, B.R. (1972). Meriones crassus. Mammalian Species 9: 1-4. Lay, D.M. (1983). Taxonomy of the genus Gerbillus (Rodentia: Gerbillinae) with comments on the applications of generic and subgeneric names and an annotated list of species. Zeitschrift für Sàugetierkunde 48: 329-354.

Lay, D.M. and C.F. Nadler (1975). A study of Gerbillus (Rodentia: Muridae) east of the Euphrates River. Mammalia 39: 423-445.

Marshall, J.T., Jr. (1977a). Family Muridae: Rats and mice. pp. 396-487. In: Lekagul, B. and J.A. McNeely (eds.) Mammals of Thailand. Association for the Conservation of Wildlife, Sahakarnbhat Co., Bangkok, 758pp.

Marshall, J.T., Jr. (1977b). A synopsis of Asian species of Mus (Rodentia, Muridae). Bulletin of the American Museum of Natural History 158: 173-220.

Marshall, J.T., Jr. (1986). Systematics of the genus Mus. pp.12-18. In: Potter, M., J.H. Nadeau and M.P. Cancro (eds.) The Wild Mouse in Immunology: Current Topics in Microbiology and Immunology 127: 1-395.

Miller, G.S., Jr. (1896). The genera and subgenera of Voles and Lemmings. North American Fauna 12: 1-84.

Mishra, A.C. (1981). The hoplopleurid lice of the Indian Subcontinent (Anoplura: Hoplopeuridae). Records of the Zoological Survey of India. Miscellaneous Publication, Occasional Paper No. 21: 1-128.

Misonne, X. (1969). African and Indo-Australian Muridae: Evolutionary trends. Annales of the Museum Royal de l'Afrique Centrale, Tervuren, Belgique, Serie IN-8, Sciences Zoologiques 172: 1-219.

Musser, G.G. (1970). Species-limits of Rattus brahma, a murid rodent of Northeastern India and Northern Burma. American Museum Novitates 2406: 1-27.

Musser, G.G. (1973). Species-limits of Rattus cremoriventer and Rattus langbianis, murid rodents of Southeast Asia and the Greater Sunda Islands. American Museum Novitates 2525: 1-65.

Musser, G.G. (1979). Results of the Archbold Expeditions. No. 102. The species of Chiropodomys, arboreal mice of Indochina and the Malay Archipelago. Bulletin of the American Museum of Natural History 162: 377-445.

Musser, G. G. (1981). Results of the Archbold Expeditions. No. 105. Notes on systematics of Indo-Malayan murid rodents, and descriptions of new genera and species from Ceylon, Sulawesi, and the Philippines. Bulletin of the American Museum of Natural History 168: 225-334. 
Musser, G.G. and M.D. Carleton (1993). Family Muridae, pp. 501756. In: Wilson, D. and D.M. Reeder (eds.) Mammal Species of the World: A Taxonomic and Geographic Reference. $2^{\text {nd }}$ edition, Smithsonian Institution Press, Washington, D.C., 1206pp.

Musser, G.G. and C. Newcomb (1983). Malaysian murids and the giant rat of Sumatra. Bulletin of the American Museum of Natural History 174: 327-598.

Musser, G.G. and L.R. Heaney (1985). Philippine Rattus: A new species from the Sulu Archipelago. American Museum Novitates 2818: 1-32.

Niethammer, J. and J. Martens (1975). Die Gattungen Rattus und Maxomys in Afghanistan und Nepal. Zeitschrift für Säugetierkunde 40: 325-355.

Phillips, C.J. (1969). Review of central Asian voles of the genus Hyperacrius, with comments on zoogeography, ecology, and ectoparasites. Journal of Mammalogy 50: 457-474.

Phillips, W.W.A. (1980). Manual of the mammals of Sri Lanka. Second revised ed. Wildlife and Nature Protection Society of Sri Lanka, Vol. 1: 1-116 \& Vol. 2: 117-267. (Vol. 2 was published in 1981).

Posamentier, H. (1989). Rodents in Agriculture. A review of findings in Bangladesh. Deuhsche Gesellschatt fur Tehnische Zusammenarbeit, Eschborn, 107pp.

Pradhan, M.S. (1975). Studies of Bombay Rats. Ph.D. Thesis. Bombay University, Mumbai.

Pradhan, M.S. (1979). Application of some biochemical methods in bandicoot taxonomy. Journal of the Bombay Natural History Society 76(1): 59-65.

Pradhan, M.S. and M. Mithel (1981). White patch and its genetic control in some of the Indian rodent species. Journal of the Bombay Natural History Society 78(1): 164-165.

Pradhan, M.S. and R.P. Hemkar (1986). Present status of the European commensal Black Rat, Rattus rattus rattus (Lin.) in Bombay. Journal of the Bombay Natural History Society 83(2): 422-423.

Pradhan, M.S., A.K. Mondal and V.C. Agrawal (1989). Proposal of an additional species in the genus Bandicota Gray (order: Rodentia; fam: Muridae) from India. Mammalia 53(3): 369-376.

Pradhan, M. S., A.K. Mondal, A.M. Bhagwat and V.C. Agrawal (1993). Taxonomic studies of Indian Bandicoot rats (Rodentia: Muridae: Murinae) with description of a new species Records of the Zoological Survey of India 93(1-2): 175-200.

Pradhan, M.S., A.K. Mondal and A.M. Bhagwat (Communicated). On taxonomic status of Bandicota bengalensis lordi (Wroughton), Bandicota maxima (Pradhan et al.) and subspecies of Millardia meltada (Gray): Subfamily: Murinae; Family: Muridae; Order: Rodentia. Records of the Zoological Survey of India, Zoological Survey of India, Kolkatta.

Raman, R. and T. Sharma (1977). Karyotype evolution and speciation in Genus Rattus. Journal of Science and Industrial Research 36(8): 385-404.

Roberts, T.J. (1997). The Mammals of Pakistan. Oxford University Press, Karachi, 525 pp.

Roonwal, M.L. (1948). Three new Muridae (Mammalia: Rodentia) from Assam and the Kabaw Valley, Upper Burma. Proceedings of the National Institute of Science, India 14: 385-387.

Roonwal, M.L. (1949). Systematics, ecology and bionomics of mammals studied in connection with Teutsugamushi Disease (Scrub Typhus) in the Assam Burma War Theatre during 1945. Transactions of the National Institute of Science, India 3: 67-122.

Roonwal, M.L. (1950). Contributions to the fauna of Manipur State,
Assam. Part III - Mammals, with special reference to the Family Muridae (Order Rodentia). Records of the Indian Museum 47(1): 164.

Roonwal, M.L. and B. Biswas (1960). Additions (pp. 853-867). In: Ellerman, J.R. The fauna of India including Pakistan, Burma and Ceylon. Mammalia, Rodentia. Volume 3 (in 2 parts). $2^{\text {nd }}$ edition. Manager of Publications, Zoological Survey of India, Calcutta, (published in 1961).

Saha, S.S. (1980). Notes on some mammals recently collected from Andaman and Nicobar Islands. Records of the Zoological Survey of India 77: 119-126.

Schlitter, D.A. and K. Thonglongya (1971). Rattus turkestanicus (Satunin, 1903), the valid name for Rattus rattoides Hodgson, 1845 (Mammalia: Rodentia). Proceedings of the Biological Society of Washington 84:171-174.

Schwarz, E. (1939). On mountain-voles of the genus Alticola Blanford: a taxonomic and genetic analysis. Proceedings of the Zoological Society of London, Series B. 108: 663-668.

Spillet, J.J. (1968). The ecology of the Lesser Bandicoot Rat in Calcutta. D.Sc. Thesis published by Bombay Natural History Society, Bombay.

Sterndale, R.A. (1884). Natural history of Mammalia of India and Ceylon. Thacker, Spink \& Co., Calcutta, 263pp.

Taber, R. D., A.N. Sheri and M.S. Ahmad (1967). Mammals of the Lyallpur region- West Pakistan. Journal of Mammalogy 48(3): 329407.

Vorontsov, N.N. and E.G. Potapova (1979). [Taxonomy of the genus Calomyscus (Cricetidae). 2. Status of Calomyscus in the system of Cricetinae]. Zoologicheskii Zhurnal 58: 1391-1397 (in Russian).

Vorontsov, N.N., I.V. Kartavtseva and E.G. Potapova (1979). [Systematics of the genus Calomyscus (Cricetidae). 1. Karyological differentiation of the sibling species from Transcaucasia and Turkmenia and a review of species of the genus Calomyscus]. Zoologicheskii Zhurnal 58: 1213-1224 (in Russian). 